\title{
From second generation feed-stocks to innovative fermentation and downstream techniques for succinic acid production
}

Mancini, Enrico; Mansouri, Seyed Soheil; Gernaey, Krist V.; Luo, Jianquan; Pinelo, Manuel

Published in:

Critical Reviews in Environmental Science and Technology

Link to article, DOI:

$10.1080 / 10643389.2019 .1670530$

Publication date:

2020

Document Version

Peer reviewed version

Link back to DTU Orbit

Citation (APA):

Mancini, E., Mansouri, S. S., Gernaey, K. V., Luo, J., \& Pinelo, M. (2020). From second generation feed-stocks to innovative fermentation and downstream techniques for succinic acid production. Critical Reviews in Environmental Science and Technology, 50(18), 1829-1873. https://doi.org/10.1080/10643389.2019.1670530

\section{General rights}

Copyright and moral rights for the publications made accessible in the public portal are retained by the authors and/or other copyright owners and it is a condition of accessing publications that users recognise and abide by the legal requirements associated with these rights.

- Users may download and print one copy of any publication from the public portal for the purpose of private study or research.

- You may not further distribute the material or use it for any profit-making activity or commercial gain

- You may freely distribute the URL identifying the publication in the public portal 
1 From second generation feed-stocks to innovative fermentation and

\section{2 downstream techniques for succinic acid production}

3 Enrico Mancini ${ }^{\mathrm{a}}$, Seyed Soheil Mansouri ${ }^{\mathrm{a}}$, Krist V. Gernaey ${ }^{\mathrm{a}}$, Jianquan Luo ${ }^{\mathrm{b} *}$, 4 Manuel Pinelo ${ }^{\mathrm{a} * *}$

$5 \quad{ }^{a}$ Department of Chemical and Biochemical Engineering, Technical University of Denmark, 6 Lyngby, Denmark; 'bState Key Laboratory of Biochemical Engineering Institute of Process 7 Engineering, Chinese Academy of Sciences, Beijing, China.

8 Corresponding author information: * No. 1 North Second Street, Zhongguancun, Haidian

9 District, 100190, Beijing, China, e-mail: jqluo@ipe.ac.cn. ** Søltofts Plads, Building 227, 102800 Kgs. Lyngby, Denmark, e-mail: mp@kt.dtu.dk

11

12

13

14 
Table of Contents

17 2.0. Biomass-derived succinic acid: feedstock composition, distribution and availability .......6

18 3.0. Manufacturing succinic acid 10 


\section{From second generation feed-stocks to innovative fermentation and 38 downstream techniques for succinic acid production}

Succinic acid (SA) is one of the most important bio-building blocks in biorefinery. Its production from fermentation of renewable biomass sources is becoming a consolidated alternative that is more sustainable and potentially more economic than the traditional petroleum-based path for SA production. Fermentative production of SA has been successfully commercialized and a large and increasing number of SAderivatives are promoting the economic stability of this production. However, the companies producing SA from fermentation are targeting specialized markets and the production is far from large-scale bulk chemical synthesis. In order to develop optimized and economic processes, the best candidates in every step of the SA production process must be identified. In this paper, the most promising biomass sources, pretreatment methods, fermentation conditions (i.e. host microorganism, fermenter design and operative mode) and separation techniques for industrial SA production are critically reviewed. Selection of the host microorganism is a key factor for SA production. However, the availability, potential and sustainability of feedstocks, fermentation and separation process must also be carefully evaluated for a costeffective and environmentally sustainable SA production.

Keywords: succinic acid; lignocellulose; biomass pretreatment; membrane separation; continuous and simultaneous saccharification and fermentation; in situ product recovery; large-scale production of succinic acid.

\subsection{Introduction}

Refining biomass (biorefinery) is a promising strategy to reduce dependency on petroleum, especially with respect to chemicals and fuel production. A biorefinery addresses several challenges at the same time, such as the depletion of fossil fuel resources (with the associated consequences), the requirement for increased human sustainability of production, waste management, and political concerns (Chandel, Garlapati, Singh, Antunes, \& da Silva, 2018; Cherubini, 2010). Today, worldwide efforts are being made to develop efficient processes for bio-based production of chemicals, and succinic acid (SA) is widely recognized as a 

producing biomass-based SA, reported a reduction of more than $60 \%$ in greenhouse gasses (GHG) emissions compared to petroleum-based SA production (Succinity, 2019). Currently, more than 30 commercially valuable products can be synthetized from SA (Figure 1) or include a derivative of it, examples are: solvents and lubricants, synthetic resins, and biodegradable polymers such as polybutylene succinate (PBS) and polyamides, as well as cosmetics, food additives and pharmaceuticals intermediates (Arshadi et al., 2008; Beauprez, De Mey, \& Soetaert, 2010). Between 1999 to 2011 the global market for SA, which increased at $10 \%$ per year, more than doubled (Pinazo, Domine, Parvulescu, \& Petru, 2015) and this market is expected to grow at a CAGR (compound annual growth rate) of around 24\% by 2020 (Nghiem, Kleff, \& Schwegmann, 2017). Until recently, petrochemical-based SA dominated the market and up to 2011 biorefinery-based SA production was reported to be less than 5\% of the total SA production (IEA Bioenergy, 2012; Weastra, 2012). However, biorefinery-based SA increased to 48.7\% of the market in 2013 (EC-DGE, 2015) and was forecasted to reach even 60\% in 2015 (Pinazo et al., 2015). Pinazo et al. (2015) confirmed this trend, reporting that petrochemical-based SA production has remained stable for years, whereas SA from fermentation is responsible for the worldwide growth in SA production. In 2013 total SA production was around 38,000 t with a total market value of \$108 million (approx. 2,860 \$/t), while petrochemical-based global SA production was approximately 40,000 t with a market value of \$100 million (approx. 2,500 \$/t). In 2015 the estimated addressable market for SA-derived chemicals was between \$7 and \$10 billion, including 1.4 butandiol (BDO - up to \$4 billion), tetrahydrofurane (THF) and oxalan-2-one (GBL) (ECDGE, 2015). Because of the wealth of industrial activity focused around biorefinery-based SA production, SA was reported as the fastest growing bio-based market in 2015. If SA from 90 fermentation is economically competitive, it could easily replace many fossil-based building 
91 block alternatives. In a report entitled "From the sugar platform to biofuel and biochemicals", the European Commission places SA production at a TRL between 7 and 8 today. This means that some processes are at commercial scale, while others still need further research and development to enter the market (EC-DGE, 2015). However, whilst significant advances have been made in the field, barriers remain for full exploitation of lignocellulose (EC-DGE, 2015) which is expected to be the future major feedstock for industrial SA production (Efe, van der Wielen, \& Straathof, 2013; C. S. K. Lin et al., 2013).

Succinic acid has traditionally been a petrochemical by-product obtained from catalytic hydrogenation, paraffin oxidation and electrolytic reduction of maleic anhydride or maleic acid (Xu et al., 2018). The liquid-phase maleic anhydride hydrogenation to succinic anhydride is followed by the hydration to SA (Figure. 2) (Pinazo et al., 2015). The petrochemical synthesis of SA occurs by means of Ni or Pd based catalysts at a temperature between 120 to $180{ }^{\circ} \mathrm{C}$ and moderate hydrogen pressure of 0.5 to $4.0 \mathrm{MPa}$, which saturates the double bonds to release heat $\left(\Delta H=-133.89 \mathrm{~kJ} \mathrm{~mol}^{-1}\right)$ (Fumagalli, 2006). The process efficiency reported in the literature is limited to the first step only (from maleic anhydride to succinic anhydride, see Figure 2) with yields close to the theoretical yield

107 (Fumagalli, 2006; Pinazo et al., 2015). However, purification steps are still required to obtain a marketable product, and after removing the catalyst by filtration, the raw succinic anhydride is distilled under vacuum conditions and subsequently flaked (Fumagalli, 2006). SA can also be chemically synthesized from levulinic acid, which is another

111 renewable feedstock that can be easily obtained from lignocellulose treatment. The process is 112 reported to be economically competitive compared to SA production from petroleum, and 113 offers also advantages compared with SA from fermentation of lignocellulose (Cukalovic \&

114 Stevens, 2008). Nevertheless, SA synthesis from levulinic acid has only recently received 115 attention and is currently still far from full-scale implementation (Kawasumi et al., 2017). In 
116 contrast, several industrial actors such as: Biosuccinium (former Reverdia), Succinity,

117 BioAmber and Myriant (Table 1), have already successfully commercialized SA based on

118 microbial fermentation. To develop more economic and optimized bio-based processes,

119 identification of the best candidates in every step must be performed.

120 This work comprehensively reviews the most recent advances in the development of

121 cost-efficient second generation biorefinery processes for SA production with an emphasis on

122 large-scale synthesis, and takes a look at the future. There are four main sections: the first

123 investigates the characteristics and availability of biomass feedstock candidates with a focus

124 on second generation biorefineries; the second provides an overview of the potential of SA

125 production from different feedstock candidates and reviews the relevance of process

126 configurations and operational modes that can be applied in the fermentation step; the third

127 section reviews the major separation techniques applied for SA separation and purification;

128 the last section identifies the best candidates for the process from a holistic point of view and

129 the associated challenges, laying solid foundations for future work in process simulation.

130 2.0. Biomass-derived succinic acid: feedstock composition, distribution and

131 availability

132 Biomass for SA production can originate from three main sources: agriculture and/or forestry

133 sources, industrial by-products, and food waste (Vassilev \& Vassileva, 2016). To date, large-

134 scale production of SA has primarily focused on starch-based sugars, but for SA not to

135 compete with food production, inexpensive lignocellulosic-derived sugars should ideally be

136 extracted from non-food crops as feedstock for SA production (Salvachúa et al., 2016).

137 First generation feed-stocks for SA production are typically rich in carbohydrates, for

138 example wheat, corn, sugar beet, sugar cane or direct use of refined sugars, for example

139 glucose (Salvachúa et al., 2016). For many of the plant sources of such carbohydrates, 
140 however, only a small fraction of the aerial parts of the plant is utilized for SA production

141 (Cherubini, 2010). Reduced chemical complexity and high concentration of degradable

142 carbohydrates are the major advantages of the first generation feed-stocks. SA production has

143 low dependence on a single feedstock since it can be chemically produced from basically any

144 carbohydrate fraction (Table 4). This flexibility is useful in overcoming seasonal and

145 geographical limitations that may be associated with producing biomass-based biorefinery

146 products.

Lignocellulosic biomass has been proposed as the future feedstock for SA production

148 (Efe et al., 2013; C. S. K. Lin et al., 2013). Unlike first generation feedstock, lignocellulosic

149 biomass encompasses nearly the whole plant (Cherubini, 2010). The composition of such

150 biomass ranges from $40-50 \%$ cellulose and $20-40 \%$ hemicellulose and lignin (Cherubini, 2010) and represents a cheap and abundant feedstock as well as a way to dispose of agricultural wastes (Mulvihill, Beach, Zimmerman, \& Anastas, 2011). Fermentable sugars obtained from cellulose and hemicellulose, such as glucose, xylose, fructose, lactose are the sources for SA production (Werpy \& Petersen, 2004). The annual production of lignocellulosic material from the agriculture industry and terrestrial plants is estimated to be about 180 million tons per year (Figure 3).

Food waste represents a rather diffuse unexploited (or not fully exploited) resource throughout the entire world. Nowadays, the vast majority is landfilled, burnt, or in the bestcase scenario anaerobically digested for biogas production (C. S. K. Lin et al., 2013). Many

160 studies have highlighted the great potential of food waste as potential feedstock for chemical synthesis (Brunklaus B, Rex E, Carlsson E, 2018; Erica, 2004; C. S. K. Lin et al., 2013). In 2012 the amount of dumped food worldwide was estimated to be around 1.3 billion $t$ (1/3 of

163 the food production) (Buchner et al., 2012), with FAO reporting as much as $50 \%$ of food

164 wasted in the supply chain and after reaching the consumers. In the European Union, 89 
million tons of food are wasted yearly, with $80 \%$ of this figure coming from manufacturing (38\%) and household waste (42\%) (C. S. K. Lin et al., 2013). In this respect, it is important to mention that SA has been produced successfully from selected food waste samples (Q. Li, J. A. Siles, I. P. Thompson, 2010; Zhang et al., 2013).

Bakery and bread wastes have been pointed out as particularly suitable for SA production because they are rich in easily fermentable carbohydrates (starch and simple sugars) and can provide the required nutrients for efficient SA biosynthesis (A. Y. Z. Zhang et al., 2013). Leung, Cheung, Zhang, Lam, \& Lin (2012) used bread waste for solid state fermentation, and from the $59.8 \mathrm{wt} \%$ detected starch per gram of bread (dry weight), they obtained as much as $90.8 \%$ conversion to glucose, resulting in a sugar concentration of more than $100 \mathrm{~g} / \mathrm{L}$ after hydrolysis. Similar amounts of carbohydrates were reported by Zhang et al. (2013) in pastry and cake residues, at 33.5 and 62.0\% (g carbohydrate/g residue), respectively. Treatment of a 30\% (w/v) solution residue, i.e. 10.05 g carbohydrate/L, with simultaneous hydrolysis and fungal autolysis released about 54.2 and $58.7 \mathrm{~g} / \mathrm{L}$ glucose plus fructose, for pastry and cake residues, respectively.

Citrus peel waste has also been studied for SA production. The major components of citrus waste are water (80 wt\%), soluble sugars, cellulose up to $23.17 \pm 0.64 \mathrm{wt} \%$ (dry weight) (Q. Li et al., 2010), hemicellulose, pectin and D-limonene. It is estimated that 31.2 million tons of citrus fruits are annually processed in the world, half of which is waste (calculated on a wet basis). This waste comes mainly from oranges, lemons, limes, grapefruits and tangerines, which are therefore potential substrates for SA production (Q. Li et al., 2010; C. S. K. Lin et al., 2013). Seventy percent of the world's supply in citrus fruits originates from Brazil, Italy, Spain, China, India, Egypt, South Africa, Morocco, Turkey, and USA (C. S. K. Lin et al., 2013). 

have reported on the potential of this low-cost substrate to produce SA in high concentration and yield by using different bacterial hosts (Lee, Lee, Hong, \& Chang, 2003; Samuelov,

192 Datta, Jain, \& Zeikus, 1999; Wan, Li, Shahbazi, \& Xiu, 2008). Cheese whey contains about $1934.9 \%$ carbohydrate and 6 to $7 \%$ solids of which 70 to $80 \%$ is lactose and $10-15 \%$ consists of 194 milk proteins, lactate and salts (Samuelov et al., 1999). After separation of lactose-rich and protein-rich fractions, the former could be used for SA production via fermentation (C. S. K. Lin et al., 2013). Whey production in the U.S., expressed as dry matter, is about 470,332 t

197 (European Commission, 2018), whereas the global production was about 2.6 million tons in 2014 (FAO, 2018). Due to its high biological oxygen demand (BOD), whey cannot be

199 released into the environment and most of it is disposed of (Lee, Lee, Hong, \& Chang, 2003) or used in animal feed blends (Samuelov et al., 1999). The high organic carbon content makes cheese whey a good substrate for SA production but it lacks available nitrogen (Lee, Lee, Hong, \& Chang, 2003). As a consequence, significant amounts of nitrogen could be necessary to produce SA from whey (Pateraki et al., 2016). Glycerol is a by-product of the biodiesel and bioethanol industries, and about $100 \mathrm{~mL}$ glycerol is produced with every liter of biodiesel (Borzani, 2006; Carvalho, Matos, Roca, \& Reis, 2014). Glycerol is highly promising as a substrate for SA production due to its higher reduced chemical status as compared to C5 and C6 sugars (Pateraki et al., 2016). The cost of raw glycerol is low but its quality largely depends on the feedstock used and the quality of the produced biodiesel (Carvalho et al., 2014).

211 vary significantly depending on the species and/or the growth conditions. This variety makes

212 this biomass very versatile for numerous commercial applications, such as production of

213 biofuel, biochemicals, pharmaceuticals, food etc. The amount of algal carbohydrates reported 
in the literature is on average $29.9 \mathrm{wt} \%$ with a maximum of $83.6 \mathrm{wt} \%$ and a minimum of 4.0 wt\% (Vassilev \& Vassileva, 2016).

To summarize, nearly all food crops production has been constantly increasing during

217 the last 50 years - for example, fresh fruits and cereals production rose by around 4.5 fold

218 (FAO, 2018) - and this growth has also generated a constant increase in lignocellulosic

219 residues that can be utilized under the biorefinery concept. In this sense, the main SA production from lignocellulose could be supplemented with that from local organic solid waste (including food waste) or by exploiting regional resources. Important local resources for SA production are: algae from areas close to the sea, non-food crops such as grass, industrial wastes such as glycerol, cheese whey, spent sulfite liquor (from paper industry), citrus peel etc.

\subsection{Manufacturing succinic acid}

\subsection{Feed-stocks potential}

Waste biomass from cereal processing has been widely investigated as a potential feedstock for SA production. The overall potential yield of SA from corn stover under different conditions was $74 \pm 2$ wt\% (J. Li et al., 2011; Salvachúa et al., 2016; Zheng et al., 2010) when the process was started from straw hydrolysates only. Zheng, Dong, Sun, Ni, \& Fang (2009) reported a higher SA yield from corn straw (81 $\pm 2 \mathrm{wt} \%$ ) compared with that from wheat straw (74 $\pm 2 \mathrm{wt} \%$ ) and rice straw (63 $\pm 2 \mathrm{wt} \%)$. The same authors reported a yield as high as $89 \pm 3$ wt\% from corncob only, which highlighted the potential of using specific parts of the corn stover for SA production. The potential of corn stalks for SA production is also relatively high in the lignocellulosic wastes group, and yields of about $83-87$ wt\% have been reported (Liang et al., 2013; D. Wang et al., 2011). Sugarcane bagasse and molasses are also 
attractive biorefinery substrates due to their potential SA yield. Reported yields for the former

238

239

240

241

242

243

244

245

246

247

248

249

250

251

252

253

254

255

256

257

258

259

260 are around $40 \mathrm{wt} \%$ (Borges \& Pereira, 2011) up to $80 \mathrm{wt} \%$ (Chen, Tao, \& Zheng, 2016) when multiple enzymatic pretreatment is applied. While for sugar cane molasses SA yields are between nearly $70 \mathrm{wt} \%$ (Cao et al., 2018b) to 80 wt\% (Liu et al., 2008; Shen et al., 2015), depending on the pretreatment steps and nitrogen sources. For both sugarcane bagasse and molasses A. succinogenes was used as the microbial host.

Bread and bakery wastes are rich in fermentable carbohydrates and have a good potential for biochemical SA production, with values of 55\% (g SA/g bread) from solid-state fermentation (Leung et al., 2012) and between 28 and 35\% (g SA/g total bakery waste) (A. Y. Z. Zhang et al., 2013). In the UK alone, waste from bakeries and dried food amounted to 1 million $\mathrm{t}$ in 2009. The conclusion is that relevant quantities of succinic acid can be produced via fermentation of bakery products (C. S. K. Lin et al., 2013). For citrus waste, most of which is peels, about 15.6 million t (wet basis) of citrus waste is produced yearly worldwide (Q. Li et al., 2010; C. S. K. Lin et al., 2013). Q. Li et al., (2010), studied the potential SA production from different concentrations of pretreated orange peel through exposing the peel to the cellulolytic bacterium $F$. succinogenes S85 in an anaerobic batch reactor under a carbon dioxide atmosphere. After removing D-limonene (see section 3.2), fermentation of 10 g/L orange peel gave a maximum yield of more than 12\% (g SA/g pretreated orange peel) with a production rate of $10 \mathrm{mg} / \mathrm{L} / \mathrm{h}$. Increasing the orange peel concentration significantly lowered the yield to about a third $(<4 \%$ - g SA/g pretreated orange peel at 60 g pretreated orange peel /L) but more than doubled the productivity (25 mg/L/h). Regarding cheese whey, SA yields are reported to be between 57 to 91 wt\% depending on the microbe used and the fermentation conditions (K.-K. Cheng, Zhao, Zeng, \& Zhang, 2012; Samuelov et al., 1999; Wan et al., 2008). 


\subsection{Pretreatment of biomass for SA production}

262 Biomass pretreatment is essential to make the carbohydrates of the selected raw material available for fermentation. An efficient pretreatment aims to make as much as possible of the carbohydrate fraction of the biomass accessible while at the same time removing potentially inhibiting compounds in the mixture. On the other hand, feedstock production and grid intensity in biomass pretreatment for SA production is reported as a major source for GHG emissions (EC-DGE, 2015).

SA production from agricultural crops can exploit the already established treatment processes of food production. Du et al. (2008) suggested that the processing of the raw material fractions (e.g. flour separated from bran) and subsequent formation of a common feedstock for fermentation and SA production is more economic and sustainable. These authors reported that SA production from an integrated wheat biorefinery was twice that obtained from a biorefinery process not using fractionation of the raw material; SA yields of $40 \mathrm{wt} \%$ (Du et al., 2008) were obtained for the former process compared to $19 \mathrm{wt} \%$ for the latter (Du, Lin, Koutinas, Wang, \& Webb, 2007).

With lignocellulosic material, pretreatment may involve harsh conditions to break down the robust lignocellulosic structure, and operations vary from simple drying and grinding (Q. Li, et al., 2010) to steam explosion at $215^{\circ} \mathrm{C}$ for 3 - 6 min (Kim et al., 2004; Lee, Lee, Hong, Chang, \& Park, 2003). Nonetheless, enzymatic pretreatments (after thermochemical treatments) were reported as being less complex and more efficient and sustainable than non-enzymatic pretreatments and extracted up to $90 \%$ of the sugars (Chandel et al., 2018). Table 2 collects the advantages and disadvantages of the different pretreatment methods. However, the process itself may produce toxic compounds (see section 3.4). 
a deacetylation pretreatment before a diluted acid pretreatment to corn stover. When this deacetylated corn stover was compared to pure sugar as a substrate for SA production, the production rate only was lower while the final SA titer and yield were the same: a titer of 43 and $47 \mathrm{~g} / \mathrm{L}$ and yield of 72 and $74 \mathrm{wt} \%$ for corn stover and pure sugar, respectively. The corn stover was knife-milled, sieved through a $19 \mathrm{~mm}$ mesh and deacetylated for $2 \mathrm{~h}$ in a bath of $0.4 \mathrm{wt} \% \mathrm{NaOH}$ and $80^{\circ} \mathrm{C}$, for a corn stover with $8 \mathrm{wt} \%$ total solids (TS). The pretreatment was then run for 10 minutes at $160^{\circ} \mathrm{C}$ with addition of $8 \mathrm{~g} \mathrm{H}_{2} \mathrm{SO}_{4}$ per $\mathrm{kg}$ of biomass. When deacetylation was performed before dilute acid pretreatment of corn stover, SA production yield was $42 \%$ higher ( $0.74 \mathrm{~g}$ SA/g sugars) with a $370 \%$ increase in production rate $(1.27 \mathrm{~g}$ $\mathrm{SA} / \mathrm{L} / \mathrm{h})$ than SA yield (0.52 g SA/g sugars) and production rate $(0.27 \mathrm{~g} \mathrm{SA} / \mathrm{L} / \mathrm{h})$ without prior deacetylation. The gap between the theoretical yield and the obtained production in the experiment reported by Salvachúa et al. (2016) (1.12 and 0.74 g SA/g sugars, respectively) was explained by the generation of other co-products (i.e. formate, acetate) and biomass formation of $A$. succinogenes.

Food waste pretreatment might involve a simple blending followed by enzymatic hydrolysis and fungal autolysis, such as for bread and bakery waste (Leung et al., 2012; A. Y. Z. Zhang et al., 2013), or may require more complex steps, such as for citrus waste. For example, before conducting fermentation for producing SA, Q. Li, et al. (2010) minced citrus peel to a particle size of $2 \mathrm{~mm}$, then dried the resulting particles for $120 \mathrm{~h}$ at $65^{\circ} \mathrm{C}$ and finally applied steam to remove D-limonene which is a known antibacterial agent. According to the authors, concentrations of D-limonene of 0.06 vol\% inhibit cell growth; 0.06 vol\% corresponds to $27 \mathrm{~g} / \mathrm{L}$ orange peel. Therefore limonene must be removed from orange peel in concentrations greater than $27 \mathrm{~g} / \mathrm{L}$ prior to fermentation. japonica requires pretreating by drying, chopping and milling followed by enzymatic 
310 hydrolysis to release the intermediate sugars, such as glucose and mannose (Alvarado-

311 Morales et al., 2015; Vassilev \& Vassileva, 2016). Micro and macroalgae have huge potential

312 in a biorefinery either for fuel or for chemicals production. However, up to the present there

313 have been only few studies on using algae for SA production. In the context of the

314 biorefinery as a cluster of bio-based facilities, algae hold a key role since they have few

315 geographical limitations, do not suffer from competition with arable land, and have wide

316 natural variety in their composition. For example, Laminaria digitata and Saccharina

317 latissimi are macroalgae consisting of about $60 \%$ carbohydrates, and some other species can

318 contain more than 80\% carbohydrate (Vassilev \& Vassileva, 2016), which also makes them

319 suitable as a substrate source for SA synthesis (Holdt \& Kraan, 2011). Alvarado-Morales et

320 al. (2015) obtained a sugar solubilization of more than $78 \%$ from L. digitata, from which as

321 much as $86.5 \mathrm{wt} \%$ of the total sugars were converted to SA. Similarly, Bai et al. (2015)

322 obtained about $81 \mathrm{wt} \%$ yield of SA from total sugars from the macroalgae Laminaria

323 japonica, which was about $73 \%$ of the maximum theoretical potential.

\section{3.3. Biological synthesis}

\subsubsection{Theoretical production}

326 One part of the process utilized for SA production, the purification step, is considered as a

327 major cost driver. Therefore organisms capable of producing SA at near-maximum

328 theoretical yields would contribute considerably to the cost-efficiency of the SA production

329 process. Thus, the potential SA yield of the different feed-stocks and particularly the

330 theoretical SA yields are benchmarks for evaluating the effective bacterial performance

331 (McKinlay, Vieille, \& Zeikus, 2007). Theoretically, a mole of glucose can lead to about 1.71

332 moles of SA, as illustrated below: 
In the presence of $\mathrm{CO}_{2}$ and additional reducing power (e.g. $\mathrm{H}_{2}$ ), two moles of succinate per mole glucose can theoretically be obtained:

$$
\mathrm{C}_{6} \mathrm{H}_{12} \mathrm{O}_{6}+2 \mathrm{HCO}_{3}^{-}+2 \mathrm{H}_{2} \rightarrow 2 \mathrm{C}_{4} \mathrm{H}_{4} \mathrm{O}_{4}^{2-}+2 \mathrm{H}_{2} \mathrm{O}+2 \mathrm{H}^{+} \quad \text { (McKinlay et al., 2007) }
$$

$$
\Delta \mathrm{GH}^{0^{\prime}}=-317 \mathrm{Kj} / \mathrm{mol}
$$

Fermentation of xylose, fructose and glycerol can theoretically generate 1.43, 1.20 and 1 mol SA/mol substrate, respectively (Andersson, Hodge, Berglund, \& Rova, 2007).

\subsubsection{Fermentation: process configuration and operational techniques}

After pretreatment, the biomass can be fermented through four main process configurations and three main operational techniques. The configurations are SHF (Separate Hydrolysis and Fermentation), SSF (Simultaneous Saccharification and Fermentation), SSCF (Simultaneous Saccharification and Co-Fermentation), and CBP (Consolidated By-Processing), while the operational modes can be batch, fed-batch and continuous. The two most relevant configurations for SA production are SHF and SSF.

SHF is a configuration in which hydrolysis and fermentation occur in two separate steps and it has been largely studied for SA production as the review from Akhtar, Idris, \&

350 Abd. Aziz, (2014) shows. In SSF instead, hydrolysis and fermentation occur in the same reactor simultaneously. Temperatures used in SSF are between $37^{\circ} \mathrm{C}$ to $39{ }^{\circ} \mathrm{C}$ and $\mathrm{pH}$ is kept neutral when the host microorganism is a bacterium and low $\mathrm{pH}$ when the host is yeast (pH 3) (Chandel et al., 2018). The optimal configuration depends on the microbial host, from 
the starting feedstock (Akhtar et al., 2014). Table 3 collects the advantages and disadvantages

355

356

357

358

360

361

362

363

364

365

366

367

368

369

370

371

372

374

375

376

377 of SHF and SSF. However, one of the main conclusions from the review of Akhtar, Idris, \& Abd. Aziz, (2014) on SA production from SHF and SSF is that SFF has a promising future for SA production from lignocellulosic biomass. A recent study on organic acid production (including SA) from various lignocellulosic biomasses and through SHF and SSF confirmed the higher performance of SSF (Maslova, Stepanov, Senko, \& Efremenko, 2019). Regarding the operational techniques, companies producing SA at commercial scale use batch or fed-batch (Table 1), which are simple and efficient in terms of production yield. However, continuous production systems offer higher production rate (Table 4) and require less sterilization times (Ferone, Raganati, Olivieri, \& Marzocchella, 2019). The review of Ferone et al., (2019) on bioreactors for SA production offers a clear view of the advantages of continuous production systems, particularly for the possibility to operate the continuous with immobilized cultures (biofilm), which significantly increase the productivity. The increasing SA production yield observed when using immobilized cell bioreactors is particularly interesting for A. succinogenes. The biofilm, naturally created by this bacteria, activates and additional redox power, which permits to overcome one of the biggest limits of $A$. succinogenes in SA synthesis, which is the lack of reducing power (see section 3.3.3.) (Bradfield \& Nicol, 2016; Maharaj, Bradfield, \& Nicol, 2014). Table 3 shows major advantages and disadvantages of the main reactor's configuration and operational modes.

To conclude, SSF in a continuous bioreactor system with immobilized cells emerges as a very promising option for large-scale production of succinic acid.

\subsubsection{Succinic acid producers}

3.3.3.1. Wild-type microorganisms. SA is biologically synthetized as an intermediate in the normal metabolic pathway of several anaerobic and facultative aerobic microorganisms 
378 (Kawasumi et al., 2017). Three major pathways can be identified: (1) the TCA cycle

379 (oxidative pathway) also called the Krebs cycle, (2) the glyoxylate cycle, and (3) the

380 reductive TCA cycle. However, for wild-type microorganisms, the first two pathways cannot

381 be exploited for SA production because SA itself is an intermediate in the pathways, whereas

382 the last pathway allows the accumulation of SA in the cell (Nghiem et al., 2017).

383 Furthermore, metabolic pathways to SA by either the TCA or the glyoxylate cycle release

$384 \mathrm{CO}_{2}$ and therefore only four of the six carbons in the glycolysis pathway are preserved. In

385

386

387

388

389

390

391

392

393

394

395

396

397

398

399

400

401

402 contrast, the reductive TCA pathway can produce two four-carbon SA molecules from one six-carbon glucose molecule by incorporating $\mathrm{CO}_{2}$. Therefore the anaerobic pathway is preferred for SA production (Saxena, Saran, Isar, \& Kaushik, 2016). Most anaerobic and facultative anaerobe microorganisms ferment carbohydrates to a mixture of acids containing mainly acetic, lactate, formate and succinate as the final products of the metabolism (Van Der Werf, Guettler, Jain, \& Zeikus, 1997). Phosphoenol pyruvate (PEP) is the key intermediate in the TCA cycle, i.e. it can be converted to pyruvate and consequently to acetate, formate etc., or to oxaloacetate (OAA) then malate, fumarate and succinate (Figure 4) (Agarwal, Isar, Meghwanshi, \& Saxena, 2007; Macy, Ljungdahl, \& Gottschalk, 1978).

The reductive TCA cycle, also identified as the fermentative pathway, occurs under anaerobic conditions where the enzyme phosphoenolpyruvate carboxylase (PEPC) fixes $\mathrm{CO}_{2}$ into a molecule of phosphoenolpyruvate (PEP), converting the PEP to oxaloacetate (OAA).

Subsequently, the fermentative pathway converts OAA into malate, fumarate and finally succinate. Therefore 2 moles of $\mathrm{NADH}$ and a mole of $\mathrm{CO}_{2}$ are needed for every mole of SA produced from PEP (Figure 5).

Even though the reductive TCA cycle can potentially generate two moles of SA from a mole of glucose - instead of one as in the oxidative TCA cycle (where 2 moles of $\mathrm{CO}_{2}$ are fixed in the reductive pathway) - the maximum theoretical production is limited by the lack 
of a reductant e.g. $\mathrm{H}_{2}$ or NADH (see Figure 5) (K.-K. Cheng et al., 2012; McKinlay et al., 2007; Vemuri, Eiteman, \& Altman, 2002). Whilst engineered Escherichia coli is currently used for commercial SA production (Nghiem et al., 2017), naturally occurring wild-type E. coli produces SA as a minor fermentation product at an average of only $0.12 \mathrm{~mol} / \mathrm{mol}$ (Van

407 Der Werf et al., 1997) and up to no more than 0.2 mol of succinate per mol of glucose consumed (Chatterjee, Millard, Champion, Clark, \& Donnelly, 2001). niger, Penicillium viniferum, Byssochlamys nivea, Lentinus degener, and Paecilomyces varioti) and the yeast Saccharomyces cerevisiae (Beauprez et al., 2010; Jiang et al., 2017;

414 Nghiem et al., 2017) (Table 4). Fungi and yeasts produce SA as a by-product which they can synthetize under both aerobic and anaerobic conditions. However, production of SA seems more favorable with bacteria than with fungi because succinate has to cross two membranes

417 (mitochondrial and cytoplasmic) in fungi rather than only one in bacteria in order to be 418 excreted (Roa Engel, Straathof, Zijlmans, Van Gulik, \& Van Der Wielen, 2008). Actinobacillus succinogenes and Anaerobiospirillum succiniciproducens are known to be the highest SA producers, with the former recognized as the most promising for industrial scale SA production (Carvalho, Roca, \& Reis, 2016). M. succiniciproducens, B. fragilis (very recently screened wild-type microorganisms) and A. succinogenes can utilize various carbon 423 sources, including carbon dioxide, to produce SA (Beauprez et al., 2010). Specifically, A. succinogenes, among other carbon sources can use glycerol, maltose, lactose, fructose, xylose, arabinose etc. (Bechthold, Bretz, Kabasci, Kopitzky, \& Springer, 2008). A. succinogenes is a highly versatile host since (I) it can efficiently ferment various cheap feed427 stocks (even mixed) while fixating $\mathrm{CO}_{2}$ (Guettler, Rumler, \& Jainf, 1999), (II) it can resist to 
high glucose (S. K. C. Lin, Du, Koutinas, Wang, \& Webb, 2008) and SA (Guettler et al., 1999) concentrations, (III) it is non-pathogenic, (IV) it has the ability to form biofilms and

430 (V) can tolerate inhibitors from pretreatment e.g. furfural and HMF (Dessie et al., 2018; Diaz, 431 Blandino, \& Caro, 2018; Van Der Werf et al., 1997).

3.3.3.2. Engineered microorganisms. Natural SA producing microorganisms are limited by a series of auxotrophies (cofactors and/or nutrients) which inevitably increase the number of required substrates and the production cost (Beauprez et al., 2010). Several metabolic engineering strategies have therefore been explored to take account of the need to channel microbial pathways to SA and divert fluxes away from alternative products (McKinlay et al., 2007). However, genetic tools to modify the host must be developed (Beauprez et al., 2010) and the currently applied strategies can be grouped in four categories: (1) deletion of pathways involved in accumulation of by-product, (2) amelioration of pathways that lead to SA synthesis, (3) enhancement of substrate transport, and (4) optimization of cofactor metabolism. Recombinant Saccharomyces cerevisiae and Escherichia coli are model engineered microbes both used for commercial SA production (Table 1). pathway does not efficiently produce SA (Nghiem et al., 2017). The most important

445 advantage offered by engineered S. cerevisiae is the ability to produce SA under low $\mathrm{pH}$ 446 fermentative conditions. Such tolerance reduces the costs and efforts to neutralize $\mathrm{pH}$ during 447 fermentation (Raab, Gebhardt, Bolotina, Weuster-Botz, \& Lang, 2010). In fact, low pH 448 fermentation has been reported to be a key factor for an economic and sustainable SA 449 production (Cok, Ioannis, Alexander L., \& Martin K., 2013). However, the metabolic flux of S. cerevisiae is different and therefore, for an efficient SA production, aeration during 451 fermentation must be applied (Mazière, Pepijn, García, Luque, \& Len, 2017). 
restricted medium and thus reduce the number of required nutrients compared with naturally occurring microbes (Beauprez et al., 2010). Nonetheless, E. coli is sensitive to high acetate concentrations, which is typically found in cellulosic streams (Nghiem et al., 2017), lowering therefore the potential application of this host for second generation biomasses. Furthermore, major SA productivity of E. coli takes place through a dual-phase strategy where the produced $\mathrm{CO}_{2}$ is released and wasted (Vemuri et al., 2002). This factor also influences capital and operating costs since oxygen must be supplied for E. coli to grow (Pateraki et al., 2016).

Metabolic engineering manipulation of $A$. succinogenes where recently performed to overcome the limits of the natural strain in by-product formation, auxotrophy, $\mathrm{pH}$ tolerance and product inhibition (Dessie et al., 2018). Even though manipulations of the $A$. succinogenes’ metabolism is possible (Joshi, Schindler, McPherson, Tiwari, \& Vieille, 2014), the results are not effective as those obtained for other metabolically modified SA-producing strains (Dessie et al., 2018). However, metabolic engineering strategies of $A$. succinogenes are still at its infancy (Dessie et al., 2018; Pateraki et al., 2016). To conclude, S. cerevisiae, E. coli, and A. succinogenes amongst the best candidates for large-scale SA production. A summary of the advantages and disadvantages of their use can be found in the supplementary material Table S1.

\subsection{Separation of succinic acid}

Depending on the feedstock, pretreatment and fermentation processes, non-desired

472 by-products such as lactic acid, acetic acid and ethanol may be generated together with SA.

473 These by-products must be separated from SA since they not only reduce the purity (and thus

474 the value) of the SA stream but they also may act as inhibitors of SA production (McKinlay

475 et al., 2007). For example, pretreating lignocellulosic material could release acids (acetic, 
476 formic, levulinic), furan derivatives (furfural, 5- hydroxymethylfurfural (HMF)) and phenolic

477 compounds, such as vanillin, phenol, and p-hydroxybenzoic acid (Palmqvist \& Hahn-

478 Hagerdal, 2000). Separation of SA from the fermentation broth is estimated to account for

479 more than $60 \%$ to $80 \%$ of the total costs and represents the most important source of

480 expenses in SA production (Bechthold et al., 2008). No single specific method has been

481 identified as the best for SA separation and purification, however, the review of K. K. Cheng

482 et al. (2012) on the subject, reported direct crystallization, precipitation, membrane

483

separation, extraction, chromatography and in situ separation as major techniques for SA

separation. SA is hydrophilic and has a high boiling point. After fermentation, the next step is

usually the separation of microbial cells from the liquid phase by using membrane

technologies or centrifugation. Subsequently, SA is separated from the other compounds in

the fermentation broth and finally purified. Therefore several techniques are typically

488

integrated to separate SA from the fermentation broth. A high purity of the SA stream is

required to produce biopolymers, such as those based on butylene succinate (Alexandri et al., 2019), and the polymerization process is inhibited by fermentation by-products such as acetic and formic acid (López-Garzón \& Straathof, 2014).

\subsubsection{Membrane separation}

493 Membranes play a fundamental role in purifying fermentation products, not only downstream 494 but also during product formation itself (i.e. membrane bioreactor), and potentially lower the 495 total number of unit operations needed to manufacture SA (Alexandri et al., 2019). Cao et al. (2018) investigated the synthesis and separation of SA from glucose and $\mathrm{CO}_{2}$ with a membrane bioreactor while applying A. succinogenes as a production host. Up to $97 \%$ separation and recycling of $A$. succinogenes was obtained with a ceramic membrane of 300

499 KDa pore size and $0.16-\mathrm{m}^{2}$ surface area. This pore size was found to be the best option of the 
range studied, i.e. $0.2 \mu \mathrm{m}$, and 300, 150 and 50KDa. Cao et al. (2018) used $\mathrm{NaOH}$ to buffer

501 the pH during fermentation and consequent organic acid formation instead of the traditional

$502 \mathrm{MgCO}_{3}$.The latter is reported to be unattractive for large-scale SA production due to its cost

503 (J. Li et al., 2011), difficult solubilization and the need to handle the large amounts of $\mathrm{CaSO}_{4}$

504 that accumulate in the SA extraction process. The use of $\mathrm{NaOH}$ simultaneously enables

505 exogenous $\mathrm{CO}_{2}$ capture instead of the (by microorganisms) preferred intrinsic $\mathrm{CO}_{3}{ }^{2-}$ from $\mathrm{MgCO}_{3}$ (Cao et al., 2018a). On the other hand, high $\mathrm{Na}^{+}$concentrations are toxic and therefore the applied membrane in the bioreactor also separates $\mathrm{Na}^{+}$along with SA. Under the studied conditions of 0.4 bar $\mathrm{CO}_{2}$ and $\mathrm{NaOH}$ as buffer, the SA production from repeated

509 batch membrane bioreactors ranged from a product concentration of 27.8 to $30.4 \mathrm{~g} / \mathrm{L}$ and a 510 productivity of up to $1.39 \mathrm{~g} / \mathrm{L} / \mathrm{h}$, which identified a concentration limit for SA accumulation at which A. succinogenes was inhibited. Only partial SA purification was performed after

512 lowering the $\mathrm{pH}$ to 2.0 and recovering unconsumed nitrogen with a spiral wound NF270

513 membrane. The final SA yield and purity were not investigated, but with this membrane

514 bioreactor and in situ separation of salts, SA productivity and $\mathrm{CO}_{2}$ fixation were $1.39 \mathrm{~g} / \mathrm{L} / \mathrm{h}$

515 and $0.52 \mathrm{~g} / \mathrm{L} / \mathrm{h}$, respectively, which was an increase of $39.2 \%$ compared to batch culture.

516 Lubsungneon et al. (2014) exploited nanofiltration (NF) coupled with vapor permeation

517 (VP)-assisted esterification to purify SA from glucose-based fermentation broth. After $\mathrm{pH}$

518 adjustment to 2.0 with $\mathrm{H}_{2} \mathrm{SO}_{4}$ (to obtain organic acids in non-dissociated form - Figure 6),

519 the A. succinogenes ATTC 55618 microorganisms were removed by centrifugation and a

520 subsequent cross-flow microfiltration unit (MF), which achieved up to $80 \%$ protein removal

521 (to $0.48 \mathrm{~g} / \mathrm{L}$ ). The authors reported membrane fouling by macromolecules and protein

522 adsorption as one of the main issues during the process. The final step was SA recovery

523 carried out through NF and subsequent VP-assisted esterification. Diananofiltration with a

524 tubular membrane module (membrane surface area of $55 \mathrm{~cm}^{2}$ made of a selective layer of 
$525 \mathrm{TiO}_{2}$ coated on the supportive $\alpha-\mathrm{Al}_{2} \mathrm{O}_{3}$ layer) was used to separate organic acids from the

526 fermentation broth. The subsequent SA recovery yield (in the retentate) was up to $98 \%$ of the

527 original concentration detected in the fermentation broth before separation. The filtration was

528 carried out over $205 \mathrm{~h}$ and under a pressure of $400 \mathrm{KPa}$, at a $\mathrm{pH}$ equal to 2.0 and temperature

529 of $30.5^{\circ} \mathrm{C}$. To separate SA from the other organic acids, Lubsungneon et al. (2014) applied a

530 VP-assisted esterification. Permeate was concentrated with a rotary evaporator and then SA

531 was esterified with ethanol to produce diethyl succinate (highest reaction rate $11.13 \mathrm{~g} / \mathrm{L} / \mathrm{h}$ at

$53280-95^{\circ} \mathrm{C}$, equilibrium time reached in 60 to $90 \mathrm{~min}$ ). The reaction also generated water and

533 highly pure diethyl succinate was obtained through water removal (dehydration) which

534 consequently shifts the equilibrium towards product formation. Afterwards vacuum

535 distillation was applied, followed by ethanol dehydration (in VP with a NaA zeolite

536 membrane) and recirculation. The diethyl succinate was then hydrolyzed to obtain highly

537 pure SA as the final product.

538 Electrodialysis is a technology based on altering the concentration of electrolytes in a

539 solution and transporting them to another solution that is separated from the first solution by

540 an ion-exchange membrane. The driving force is the applied electrical potential. A key study

541 on SA recovery from a fermentation broth through electrodialysis was done in US Patent No.

$5425,143,834$ (1992). In this study, A. succiniciproducens was grown on corn steep liquor and

$543 \mathrm{CO}_{2}$ and SA purification was performed as follows: (1) the cells and succinate (as well as the

544 other ions) were separated from uncharged compounds e.g. proteins and from the water by

545 electrodialysis (viable cells were recycled). Subsequently, (2) the obtained sodium succinate

546 was converted through a water-splitting electrodialysis to $\mathrm{NaOH}$ and $\mathrm{SA}$, and finally, (3) the

547 aqueous SA solution was subjected to an ion exchange purification process to obtain 60 and

$54880 \mathrm{wt} \%$ SA yield and purity, respectively. In contrast, Prochaska et al. (2018) explored

549 reactive extraction associated with bipolar membrane electrodialysis (EDBM) and obtained 

up to $90 \mathrm{wt} \%$ SA extraction from a glycerol fermentation broth. The actual post-fermentation broth $(\mathrm{pH}=8.5)$ was centrifuged for biomass removal, then filtrated with ultrafiltration, and finally subjected to EDBM. The two major advantages of EDBM are: (1) the simultaneous separation of cells (that can be recycled) and SA, with no need to incorporate a cell separation step; and (2) $\mathrm{NaOH}$ is economically and theoretically completely recyclable

555 (Yedur, Berglund, \& Dunuwila, 2001). Major disadvantages are the potential inhibition by $\mathrm{Na}^{+}$in the fermentation step (Cao et al., 2018a), potential membrane fouling (Szczygiełda, Antczak, \& Prochaska, 2017), the robustness and lifetime of EDBM (Jansen \& van Gulik, 2014), and the high capital and operative costs (K. K. Cheng et al., 2012). However, some recent studies have claimed that electrodialysis is cost-effective and can be used as a process step for SA recovery in a large-scale fermentation plant (Fu et al., 2014; Szczygiełda et al., 2017).

Overall, membrane technologies are key components in the preliminary downstream steps (such as for cell and macromolecule separation) of fermentation-based SA production (Jansen \& van Gulik, 2014). Moreover, the toxic $\mathrm{Na}^{+}$can be separated in situ when using cheaply available $\mathrm{NaOH}$ to buffer the fermentation broth. The major problem associated with membrane application is that filtration of post fermentation broths is based on pressure-driven membrane techniques, which may lead to membrane fouling phenomena (Prochaska et al., 2018). However, the physicochemical processes that occur in membrane fouling are rather well-known (C. Wang et al., 2012) and several cleaning techniques have been established at industrial scale (Shi, Tal, Hankins, \& Gitis, 2014). Due to the relevance of membrane technologies in SA separation, methods to control permeate flux decline and therefore also membrane fouling (one of the biggest problems in membrane technology) are worth to be mentioned. Actions made to reduce membrane fouling are related to (I) the selection of appropriate membrane and modulus with specific characteristics, (II) selection of the 
575

576

577

578

579

580

581

582

583

584

585

586

587

588

589

590

591

592

593

594

595

596

597

598

operating parameters, such as shear stress, permeate flux, pressure and temperature and finally, (III) adjustment of the feed-water composition with respect of foulant components, $\mathrm{pH}$ and ionic strength. In SA production membranes can be used in different steps, consequently requiring different sets of modules, membranes, and operating conditions. For removal of large-molecules when using UF a factor to control fouling is to ensure an operating pressure below the so-called threshold pressure, while in SA separation with NF, the isoelectric point of the membrane and the $\mathrm{pH}$ of the solution are key factors for an effective separation (W. Zhang, Luo, Ding, \& Ja, 2015).

\subsubsection{Precipitation}

Precipitation with $\mathrm{Ca}(\mathrm{OH})_{2}$ or $\mathrm{CaO}$ is a traditional and commercialized method for isolation of organic acids from fermentation broths. The process consists of precipitating calcium succinate by adding calcium ion sources directly into the fermentation broth. However, most specialty and commodity-based SA commercial products require free SA (Bechthold et al., 2008). Therefore, after calcium succinate recovery by filtration, SA is released by adding $\mathrm{H}_{2} \mathrm{SO}_{4}$ and subsequently purified with active carbon absorption or ion exchange. SA concentration is finally achieved by evaporation and then crystallization (US Patent No. $5,168,055,1992)$. In the patented method (US Patent No. 5,168,055, 1992), the authors separated SA from an A. succiniciproducens fermentation broth and obtained $94.2 \%$ purity. More recently, Alexandri et al. (2019) compared different methods for SA separation, including calcium precipitation. The broths were from (1) a fermented synthetic media exposed to A. succinogenes and (2) from a filtered spent sulfite liquor as feedstock (a byproduct of the paper industry) exposed to Basfia succiniciproducens. The SA yields from calcium precipitation were $8.1 \%$ and $13.1 \%$ (g dry weight of recovered SA/g dry weight of SA in the initial liquid medium) and the purities were 87.2 and $81 \%$ (g dry weight of 
recovered SA per/ g total dry weight of recovered sample) for the two fermentation broths, respectively. The SA purity from calcium precipitation was slightly lower than that reported

601 in the aforementioned patent (US Patent No. 5,168,055, 1992) (81 and 94\%, respectively),

602 but the former was from an industrial waste which is a more complex feedstock than that

603 used in the patented work, i.e. glucose. Note that the yield is the same as that reported by

604 Luque et al. (2009) who achieved a yield of 13\% (g dry weight SA recovered crystals per/g initial dry weight of SA in the fermentation broth) by applying calcium precipitation in a fermentation broth of a wheat flour hydrolysate medium exposed to A. succinogenes. Even though the application of this well-known precipitation method with $\mathrm{Ca}(\mathrm{OH})_{2}$ or $\mathrm{CaO}$ would reduce the potential risks of establishing a different technology for large-scale production of

609 SA, a large number of reagents (not repeatedly usable) is needed, which consequently

610 produce large quantities of solids and slurry e.g. calcium sulfate (produced in equal amounts

611 to SA) (Zeikus, Jain, \& Elankovan, 1999). These solids and slurries must be treated and

612 disposed of, which inevitably contributes to an increase in the operational costs. Furthermore,

613 the process is reported as being neither rapid nor energy efficient (Hestekin, Snyder, \&

614 Davison, 2002).

615 Separation based on precipitation can also be achieved by using ammonia which

616 reacts with SA to produce di-ammonium succinate. The following addition of sulfuric acid in

617 the fermentation broth leads to SA precipitation and ammonium sulfate formation.

618 Subsequent purification of SA is achieved by addition of methanol and recrystallization. The

619 reagents can be recovered by pyrolyzing the by-product, ammonium sulfate, then

620 regenerating ammonia and ammonium bisulfate. Yedur et al. (2001) patented a method based

621 on di-ammonium succinate in which by-products are nearly completely regenerated. In this

622 process, $\mathrm{pH}$ is kept neutral at 8 with ammonium cations, and the di-ammonium succinate

623 formed is then reacted with ammonium bisulfate or with sulfuric acid at very low $\mathrm{pH}$ ranges 
624 (1.5-1.8). The reaction leads to succinic acid and ammonium sulfate formation. Reagent

625 regeneration was carried out at about $300^{\circ} \mathrm{C}$ by cracking the ammonium sulfate. The

626 maximum final reported SA yield was $93.3 \mathrm{wt} \%$. The advantage of using ammonia

627 precipitation is reduced waste formation and the fact that the reagents are to a large extent

628 reusable. The main drawbacks are the high energy consumption for reagent regeneration and

629 corrosion of equipment due to the low pH (K. K. Cheng et al., 2012). It is worth highlighting

630 that this technology is currently used by Myriant in a 14kt/y SA plant in the United States

631 (Table 1).

632

\subsubsection{Crystallization}

633 Direct crystallization either from acidification or using ion exchange resins has provided

634 better performances than traditional calcium precipitation (Alexandri et al., 2019; Luque et

635 al., 2009). Luque et al. (2009) separated SA by vacuum distillation-crystallization from two

636 synthetic broths and one real fermentation broth from which $35.7 \mathrm{~g} / \mathrm{L}$ of SA were produced

637 from a wheat flour hydrolysate medium exposed to A. succinogenes. After removal of

638 biomass and impurities from the fermentation broth by centrifugation, membrane filtration

639 and activated carbon, separation was applied using vacuum distillation (at $60^{\circ} \mathrm{C}$ ) and

640 subsequent crystallization (at $4^{\circ} \mathrm{C}$ ) under controlled $\mathrm{pH}$ conditions (kept at 4.2) with

641 hydrochloric acid. Selective SA crystallization from the fermentation broth was achieved by

642 exploiting the different solubility of organic acids, which resulted in a purity of $45 \%$ (g SA

643 crystals per/g total acid crystals) and yield of 28\% (g dry weight SA recovered crystals per/g

644 initial dry weight of SA in the fermentation broth). This result represented a $50 \%$ and $87 \%$

645 improvement in purity and yield, respectively, compared to a calcium precipitation process.

646 Much better results were reported from mock hydrolysates used, to obtain up to 97 and 75

647 wt\% purity and yield, respectively. Similar purity but much higher yield was obtained with 

direct crystallization (60-75 wt\%) compared to calcium precipitation (20-27 wt\%) of mock hydrolysates (Luque et al., 2009). Currently, the highest SA recovery purity and yield values from direct crystallization were reported by S. K. C. Lin et al. (2010). These authors exposed a wheat hydrolysate medium to A. succinogenes and reported up to 99 and $89.5 \mathrm{wt} \%$ purity and yield, respectively, as a result of applying a resin-based vacuum distillationcrystallization method. Interestingly, Alexandri et al. (2019) in their comparative study of different downstream separation processes, identified vacuum evaporation, cooling rate and the previously reported pH (S. K. C. Lin et al., 2010) as the key factors for a successful crystallization process. Vacuum evaporation enabled acetic and formic acid removal (which prevent SA crystallization), while $\mathrm{pH}$ and cooling rate affected the form in which SA was obtained (dissociated or non-dissociated - Figure 6) and the crystal formation process, respectively. Optimal $\mathrm{pH}$ for direct crystallization of SA was reported at $\mathrm{pH} 2.0$, where SA is non-dissociated and can be selectively crystallized with higher yields (S. K. C. Lin et al., 2010). Under this $\mathrm{pH}$ condition, only 3 to $4 \%$ of SA is solubilized, while the other organic acids e.g. acetic acid and lactic acid are fully water miscible (S. K. C. Lin et al., 2010). However, Alexandri et al. (2019) reported higher purity and yield by means of ion-exchange resins compared to just lowering the $\mathrm{pH}$ to 2.0 (with $\mathrm{H}_{2} \mathrm{SO}_{4}$ ). Specifically, after vacuum distillation and crystallization, the SA yield and purity from a real fermentation broth were, respectively, 38.6\% and 6.7\% higher from cation-exchange than from $\mathrm{pH}$ decrease $(79 \%$

667 yield and 96\% purity from cation-exchange and 57\% yield and 90\% purity from lowering the $668 \mathrm{pH}$ ). The lower values in the work of Alexandri et al. (2019) compared to the values reported 669 in the work of S. K. C. Lin et al. (2010), i.e. 99\% yield and 89.5\% purity, were attributed to 670 the higher complexity of the spent sulfite liquor used by the former authors instead of the 671 wheat hydrolysates used by S. K. C. Lin et al. (2010). High SA purity with less than 0.09 672 mol\% of impurities is required for polymer synthesis (Alexandri et al., 2019). Even though 
673 direct crystallization enables a rather good yield of SA crystals to be obtained without many

674 unit operations (Q. Li, Wang, et al., 2010), the purity is low since other compounds in the

675 fermentation broth can crystallize with SA (Q. Li, Wang, et al., 2010; Thuy, Kongkaew,

676 Flood, \& Boontawan, 2017). Therefore crystallization is used and recommended as the final

677 step to purify SA (K. K. Cheng et al., 2012).

\section{3.4.4. Extraction}

679 Salting out is a potential SA separation method which simultaneously removes cells and

680 proteins from the fermentation broth and thus centrifugation and filtration steps can be omitted (Sun, Yan, Fu, \& Xiu, 2014). The process is based on the interaction between electrolyte and non-electrolyte compounds, where (the non-electrolyte) would become less soluble under high salt concentration conditions and as a consequence precipitates out. The method allows the extraction of hydrophilic compounds, such as some organic solvents, from an aqueous solution. For example, Sun et al. (2014) investigated SA separation from a real (glucose-based fed-batch fermentation) and a synthetic fermentation broth by means of salting out and subsequent crystallization. The salting out mechanism for SA separation is governed by factors such as salt and solvent concentrations and SA dissociation form. In their study, Sun et al. (2014) first lowered the fermentation broth pH (from A. succinogenes on spent sulfite liquor feedstock) to 3.0 with $\mathrm{H}_{2} \mathrm{SO}_{4}$, then added acetone (30\%) and $\left(\mathrm{NH}_{4}\right)_{2} \mathrm{SO}_{4}$

691 (20\%) to induce SA partitioning. The SA-acetone phase was purified with activated carbon which was then removed by filtration under vacuum evaporation to enable acetone recovery. Subsequently, crystallization was carried out at $\mathrm{pH} 2.0$ and $4^{\circ} \mathrm{C}$ for $24 \mathrm{~h}$. Finally, SA crystals

694 were washed and dried at $70^{\circ} \mathrm{C}$ for $12 \mathrm{~h}$. SA yield and purity were $65 \%$ and $97 \%$,

695 respectively, from the synthetic fermentation broth, whereas the values for yield and purity 696 were $65 \%$ and $91 \%$, respectively, from the actual fermentation broth, and $99.03 \%$ of the cells 
and $90.82 \%$ of the proteins were removed by direct salting out (without any preceding

698 filtration steps). The same process was investigated by Alexandri et al. (2019) in their comparative separation and purification study (previously mentioned) which achieved 50\% and 86\% yield and purity, respectively. Even though extraction can lead to high SA purity through simultaneously separating cells and proteins from the fermentation broth and thus replacing for centrifugation and/or filtration steps, the yield is limited. Furthermore, if xylose is present in the fermentation broth, it will crystalize with SA and lower the final product purity. Therefore, since lignocellulosic material (which is rich in xylose) has been identified as the future most important feedstock for SA production, a combination of salting out and crystallization for product recovery would potentially not be a successful strategy to separate and purify the SA if the fermentation process is not highly controlled to avoid the presence of residual xylose.

To summarize, membrane separation and crystallization emerge as promising techniques for SA production from biomass fermentation. However, several combinations of

711 the mentioned separation techniques could be potentially more efficient for SA production.

\section{4.0. Perspective on process alternatives}

713 Every process and unit operation candidate potentially used for SA production has its own

714 merits and limits. Different feedstock sources and host microorganisms will (I) require different pre-treatments, (II) have different sensitivity to formation of fermentation process inhibitors, (III) require a specific set of fermentation conditions, (IV) have specific byproduct formation patterns and (V), require a different downstream technique or combination of techniques.

Companies producing SA from biomass fermentation at commercial scale targets specialized markets and the production is far from large-scale bulk SA synthesis. In addition, 
every company producing SA uses its own specific process which is different from the others (supplementary material Figure S1). Other options and potential processes have been also proposed (Klein et al., 2017; J. Li et al., 2011; Posada, Rincón, \& Cardona, 2012). Recently, Garg, Woodley, Gani, \& Kontogeorgis, (2019) carried out an extensive study which proposes a systematic methodology that integrates process synthesisintensification and it is capable of providing tools to evaluate a large search space of process alternatives. Such methodology has been applied to produce SA from a co-fermentation with $\mathrm{CO}_{2}$, obtaining a base case process alternative from a superstructure optimization approach, which was applied for process intensification. Thus, three more economic and sustainable intensified options for SA production, compared with the current processes, were developed (Figure 7). The optimized processes highlight the key role of membranes used both for the synthesis (membrane bioreactor) and in the downstream, and also put emphasis on the use of activated carbon and crystallization. However, the study of Garg et al. (2019) is based on first generation biomasses and thus, it does not include biomass pretreatment.

Therefore, more studies need to be done to find an optimal processing pathway for sustainable production of SA using a systematic approach. The lack of systematic studies on how operation conditions and equipment design affect the operating cost, with regard to fixed productivity, production and purity of SA, prevents the establishment of a standard technology for large-scale production in an economically feasible way (Figure 8). In order to carry out systematic studies, a clear view of the best candidates in every step of the succinic acid production process is needed. In terms of availability, cost, potential, efficiency and technological development, some major candidates can be identified:

(1) Feedstock. Valuable feed-stocks are glycerol, cheese whey, corn stover and other cereal crop residues, sugarcane molasses and bread and bakery wastes. Glycerol and 
cheese whey are waste streams and no pretreatment is required before fermentation, consequently reducing greenhouse gasses (GHG) emissions (EC-DGE, 2015). Furthermore, both cheese whey and glycerol could be part of an integrated biorefinery system; valuable proteins could be extracted from the former prior to fermentation to SA (C. S. K. Lin et al., 2013), while glycerol could be combined with biodiesel production (Loureiro da Costa lira Gargalo, 2017). However, depending on the host microorganism, a nutrient supply may be required to optimize the fermentation of both cheese whey and glycerol (Carvalho et al., 2014; Mansouri et al., 2013) inevitably rising the operative costs. Co-substrate fermentation, such as glycerol with Kraft paper by-product (Carvalho et al., 2014) and cheese whey with corn step liquor (Lee, Lee, Hong, \& Chang, 2003) could lower the costs of nutrient supply. High SA yields were also reported from corn stover and other crop residues. These feed-stocks are abundant and have less geographical limitations. However, harsh pretreating condition are needed to be efficiently fermented. Bread and bakery waste were also found to be optimal for SA production and provide all the required nutrients after blending and hydrolysis and fungal autolysis as pretreatment (Leung et al., 2012; A. Y. Z. Zhang et al., 2013).

(2) Pretreatment. Efficient and economic pretreatment methods allow extraction of carbon and nourishment from the feedstock while simultaneously avoiding the presence of fermentation inhibitors. While glycerol and cheese whey do not need additional challenges due to energy consuming and wastewater production pretreatment methods and the formation of fermentation inhibitors. However, some 
and successfully remove fermentation inhibitors (Salvachúa et al., 2016), leading to high SA yields (Table 4). Valuable pretreatment methods include a thermochemical step with $\mathrm{H}_{2} \mathrm{SO}_{4}$ or $\mathrm{H}_{2} \mathrm{O}_{2}$ and especially an enzymatic step (Table 2). Deacetylation with $\mathrm{NaOH}$ can also be done to limit the formation of inhibitory compounds (Salvachúa et al., 2016).

(3) Fermentation. A. succinogenes, S. cerevisiae and E. coli are the most promising and investigated SA producers. Engineered S. cerevisiae can efficiently produce SA at low $\mathrm{pH}$ saving energy and cost in the downstream, while $E$. coli offers high conversion efficiency and requires limited nutrient supply, however, both $S$. cerevisiae and E. coli require aeration for efficiently produce SA. A. succinogenes captures $\mathrm{CO}_{2}$ to produce $\mathrm{SA}$, can use various carbon sources rather efficiently, even those derived from crude renewable sources, and can adequately tolerate inhibitors. However, A. succinogenes may need nutrient supplies such as nitrogen (Pateraki et al., 2016), and its biochemistry still needs to be fully understood (Beauprez et al., 2010), which limits its potential for engineering manipulation. Another advantage of A. succinogenes is the natural ability to create biofilms, which enables chemical reactions capable of compensating the lack of cofactors in the feedstock (Bradfield \& Nicol, 2016). Biofilm shows also potential to detoxify inhibitory compounds in fermentation (Bradfield et al., 2015). Continuous systems, different from batch, can be operated with immobilized cells. Continuous operation typically has lower yields compared to batch and fed-batch but higher productivity, less sterilization times and lower contamination risks. SSF in a continuous bioreactor system with immobilized cells emerges as very promising for large-scale production of succinic acid.

(4) Downstream. The downstream of SA production can be divided into some major steps for which different technologies can be efficiently applied. 
- Cell separation. Centrifugation and/or microfiltration are typically used to separate cells from the fermentation broth (Alexandri et al., 2019). Membrane bioreactor in a continuous fermentation system and with in situ cell recycle and inhibitors removal $\left(\mathrm{Na}^{+}\right)$(Cao et al., 2018a) is highly potential (Ferone et al., 2019).

- Concentration, clarification and impurity removal. This step is done to concentrate SA and remove colors and impurities. Processes typically adopted are: evaporation for removal of water or acetic acid, solvent extraction, adsorption with activated carbon, centrifugation or ultrafiltration (K. K. Cheng et al., 2012). Adsorption through activated carbon comes out as a key step to remove colorants (Garg et al., 2019) while for protein removal, ultrafiltration has been reported to be more efficient than centrifugation (C. Wang et al., 2013) and has been widely reported as economic, low energy consuming and easily scalable (Chaiklahan, Chirasuwan, Loha, Tia, \& Bunnag, 2011; Shao, Hou, \& Song, 2010; C. Wang et al., 2012). However, membrane fouling can be severe in membrane separation (Lubsungneon et al., 2014) and inexpensive membrane fouling removal techniques need to be developed. precipitation, absorption (e.g. ion exchange resin, zeolite), reactive extraction, bipolar membrane electrodialysis, direct crystallization and nanofiltration. All these technologies have different potentials. Direct crystallization is reported to be a better solution than traditional precipitation (Alexandri et al., 2019; Luque et al., 2009), but the yield is low and impurities could crystalize with SA (K.-K. Cheng et al., 2012). Bipolar membrane electrodialysis has great potential to separate not only SA but also proteins and to recycle cell and titrant (US Patent No. 5,143,834, 1992; Yedur et al., 2001). Even though recent studies suggested bipolar membrane electrodialysis as an efficient and economical solution for large-scale SA production (Fu et al., 2014; 

840 (Mansouri et al., 2019). et al., 2019).

Szczygiełda et al., 2017), doubts about its robustness and lifetime remain (Jansen \& van Gulik, 2014; Szczygiełda et al., 2017). Nanofiltration is a rather new technology with unexplored potential for SA separation. High SA yields have been reported for use of NF, but fouling can be severe if macromolecules are not removed beforehand (Lubsungneon et al., 2014), and to date SA separation from other impurities has only been partially achieved (Choi, Fukushi, \& Yamamoto, 2008). Therefore further studies on nanofiltration selectivity to SA need to be conducted.

- Succinic acid purification and dried crystal production. The final step is product isolation and dried crystals formation. Crystallization is a major technology to produce pure SA crystals. High purity is necessary for polymers synthesis (Alexandri

The arduous task of identifying an optimal route to cost-effective and sustainable production of SA could be partially tackled by an integrated biorefinery system that combines production of SA and other building block chemicals of significant value. For example, Loureiro da Costa lira Gargalo (2017) investigated the potential of integrating SA and biodiesel production, and reported that SA production is among the top three solutions for potentially valorizing glycerol: adding SA production from glycerol carries less economic risk and improves the environmental sustainability of the biodiesel production process. In this sense, economic risk assessment of process alternatives from different feed-stocks would be essential as a decision-support tool towards process implementations for SA production

\subsection{Conclusions}

842 Succinic acid is currently an established platform chemical that forms the basis for producing 
843 several commercially valuable products and chemicals. Industrially produced SA, including

844 that derived from second generation biomasses, is entering the market. However,

845 environmentally sustainable bulk SA production requires major integration between different

846 feed-stocks and separation technologies and also requires production of other products in an

847 integrated biorefinery system; thus, systematic studies are needed in this direction. Some key

848 factors for a competitive SA production from biomass fermentation are identified in this

849 review:

- Many studies and the SA-producing companies themselves are focusing on first generation biomasses for SA production. However, various second generation biomasses show great potential and superior sustainability indicators compared to first generation biomasses. Important feed-stocks are: corn stover, wheat flour byproducts, sugarcane molasses, glycerol, cheese whey and bread/bakery wastes. However, important second generation feed-stocks, such as the lignocellulosic one, may require harsh pretreatments to be used. On the other hand, co-fermentation of strategically mixed feed-stocks can compensate auxotrophies. In each case, $\mathrm{CO}_{2}$ should be fed alongside.

- While glycerol and cheese whey do not need elaborated pretreatment and bread/bakery wastes require only simple operation, lignocellulosic feed-stocks must undergo more complex pretreating conditions. Among the various pretreatments used for the lignocellulosic matter, thermochemical steps with $\mathrm{H}_{2} \mathrm{SO}_{4}$ or $\mathrm{H}_{2} \mathrm{O}_{2}$ followed by an enzymatic pretreatment step seem to offer better performances for SA production. In addition, deacetylation during pretreatment can remove inhibitory compounds from lignocellulosic biomasses, consequently improving the SA yields and potentially reducing the separation steps in the downstream. 
- Simultaneous saccharification and fermentation (SSF) reactors have shown several advantages compared to other reactor configurations, including better performance when fermenting lignocellulosic biomasses. Most of the studies and the companies themselves use batch and fed-batch to produce SA substantially focusing on maximizing the yield from (among others) simple feed-stocks. However, continuous fermentation offers several important advantages such as cell immobilization. Simultaneous saccharification and fermentation in a continuous immobilized cell bioreactor, with in situ cell recycle has been reported to increase the biomass concentration and thus increase the overall SA productivity. At the same time the capital and operative costs would be reduced since a reduced dilution is required, consequently reducing the needed rector size.

- Engineered E. coli and S. cerevisiae are well established and efficient hosts for SA production, however, pathogenicity, required aeration, emission of $\mathrm{CO}_{2}$ during production and low tolerance to some inhibitors are important limitations to their utilization. A. succinogenes is a promising host and the development of engineering tools for metabolic pathway manipulations, together with the development of integrated biorefinery strategies, could open the door to the large-scale utilization of A. succinogenes for SA production.

- Succinic acid recovery should be carried out at low pH, since lower environmental impacts have been reported under those conditions. However, only yeasts, such as $S$. cerevisiae, can tolerate low pH conditions. Membranes, activated carbon and crystallization appear as key technologies for downstream processing of SA. 
891 superstructure optimization that may suggest viable processes and sequences of processes for 892 feasibly large-scale production of SA.

893

894 


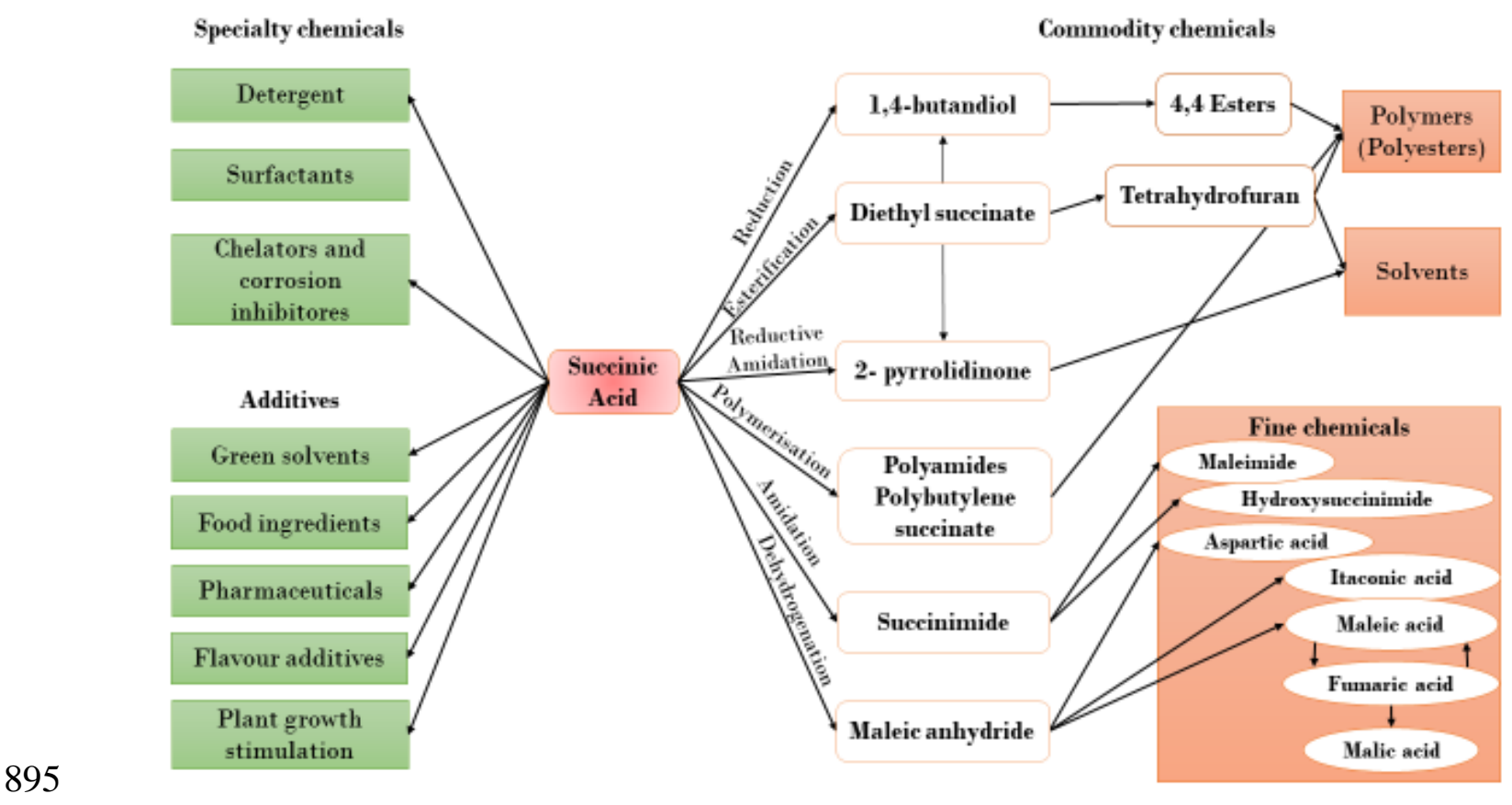

896 Figure 1. Overview of some selected specialty and commodity chemicals that can be 897 synthetized from succinic acid (Arshadi et al., 2008; McKinlay et al., 2007).

898

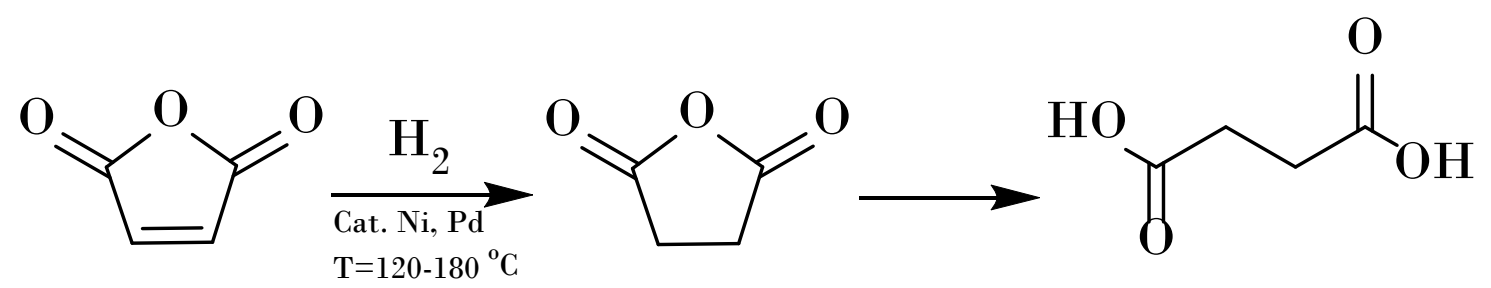

899

Maleic Anhydride

Succinic Anhydride

Succinic Acid

900 Figure 2. Production of succinic acid from petrochemical derived maleic anhydride. 


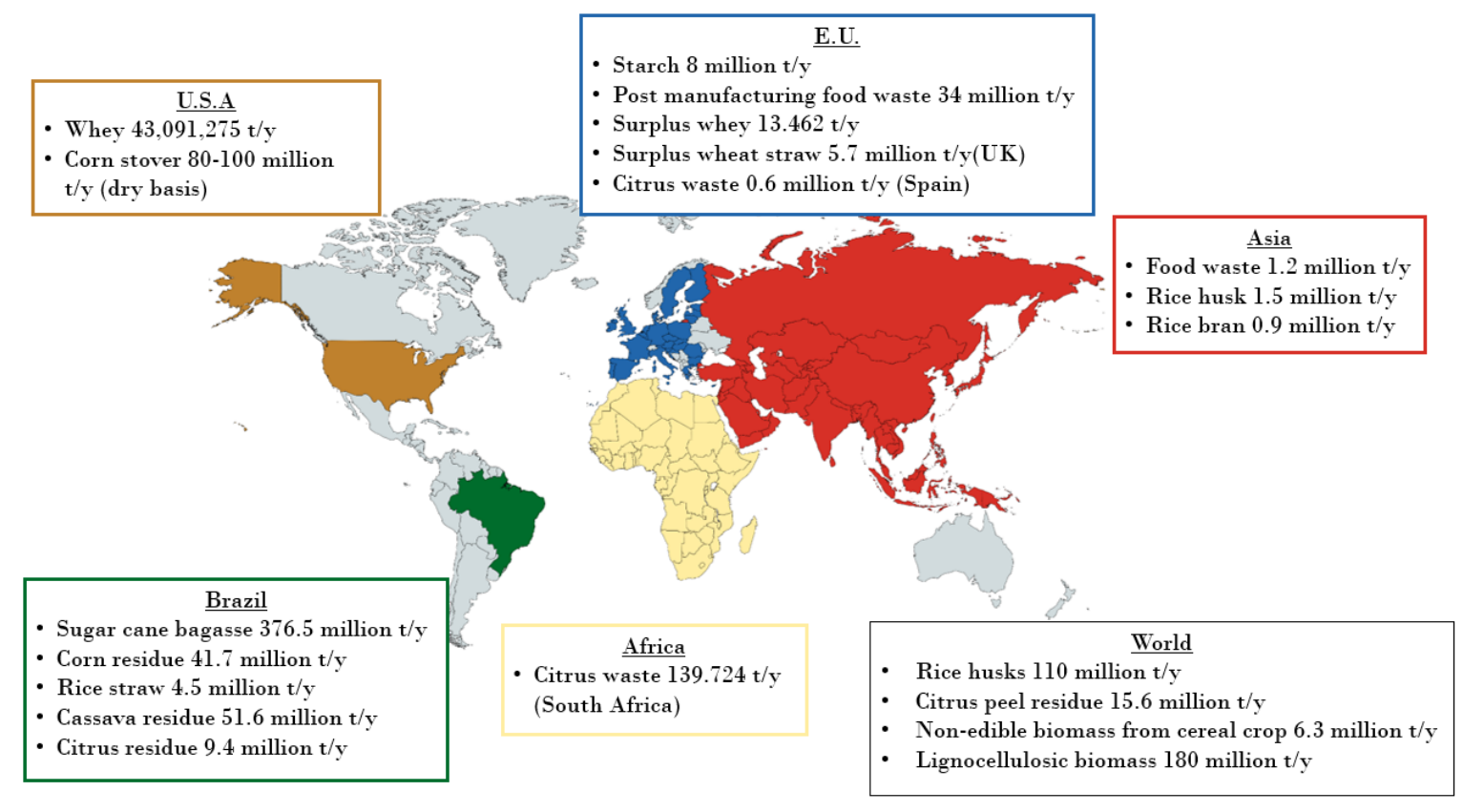

903 Figure 3. Distribution of world food waste that would be suitable for succinic acid

904 production. With the exception for data on rice waste in Asia, which are from the work of

905 Gunarathne et al. (2019), all the other data are based on the work of C. S. K. Lin et al. (2013)

906

907<smiles>C=C(OP(=O)([O-])[O-])C(=O)O</smiles>

909 Figure 5. Reductive process in the tricarboxylic acid cycle (Saxena et al., 2016). 


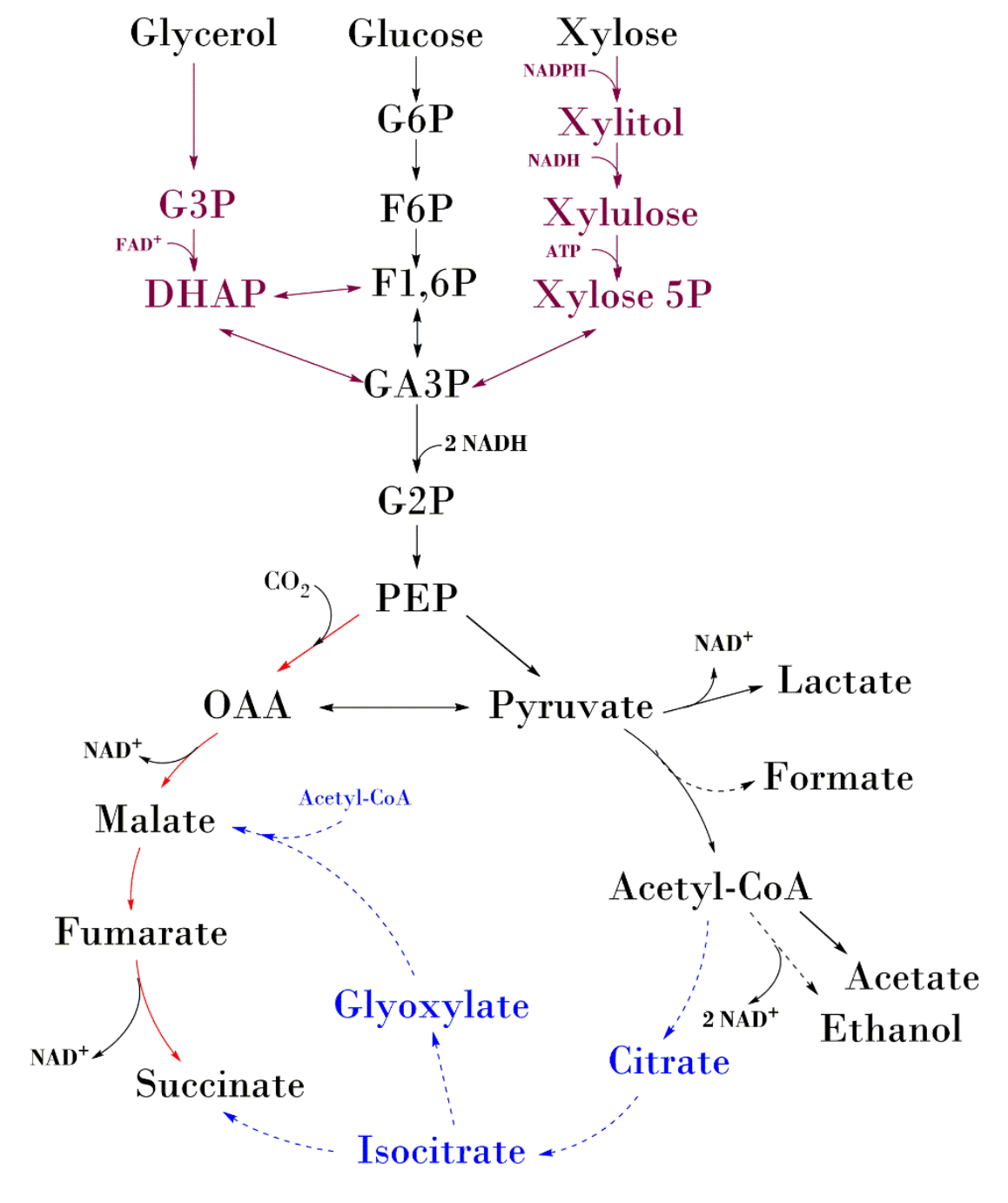

912

913 Figure 4. General TCA cycle found in many natural fermentative microorganisms, including

914 E. coli, A. succinogenes, A. succiniciproducens and M. succiniciproducens. Lactate is not

915 produced by A. succinogenes, ethanol is not produced by M. succiniciproducens when grown

916 on glucose, and A. succiniciproducens does not synthetize formate (McKinlay et al., 2007).

917 The reductive pathway of the TCA cycle is shown in red, while the pathway that specifically

918 occurs in A. succinogenes for xylose and glycerol is shown in red burgundy. The glyoxylate

919 shunt and the oxidative branch of the TCA cycle represented in blue (Carvalho et al., 2014;

920 McKinlay et al., 2007; Pateraki et al., 2016; Xu et al., 2018). These metabolic pathways are

921 exploited in anaerobic succinate engineered E. coli (McKinlay et al., 2007). G6P: glucose-6-

922 phospate; F6P: fructose-6-phospate; F1.6P: fructose-1,6-biphosphate; G3P: glycerate-3-

923 phosphate, GA3P: glyceraldehyde-3-phosphate; G2P: glycerate-2-phosphate; PEP:

924 phosphoenolpyruvate; OAA: oxaloacetate. 


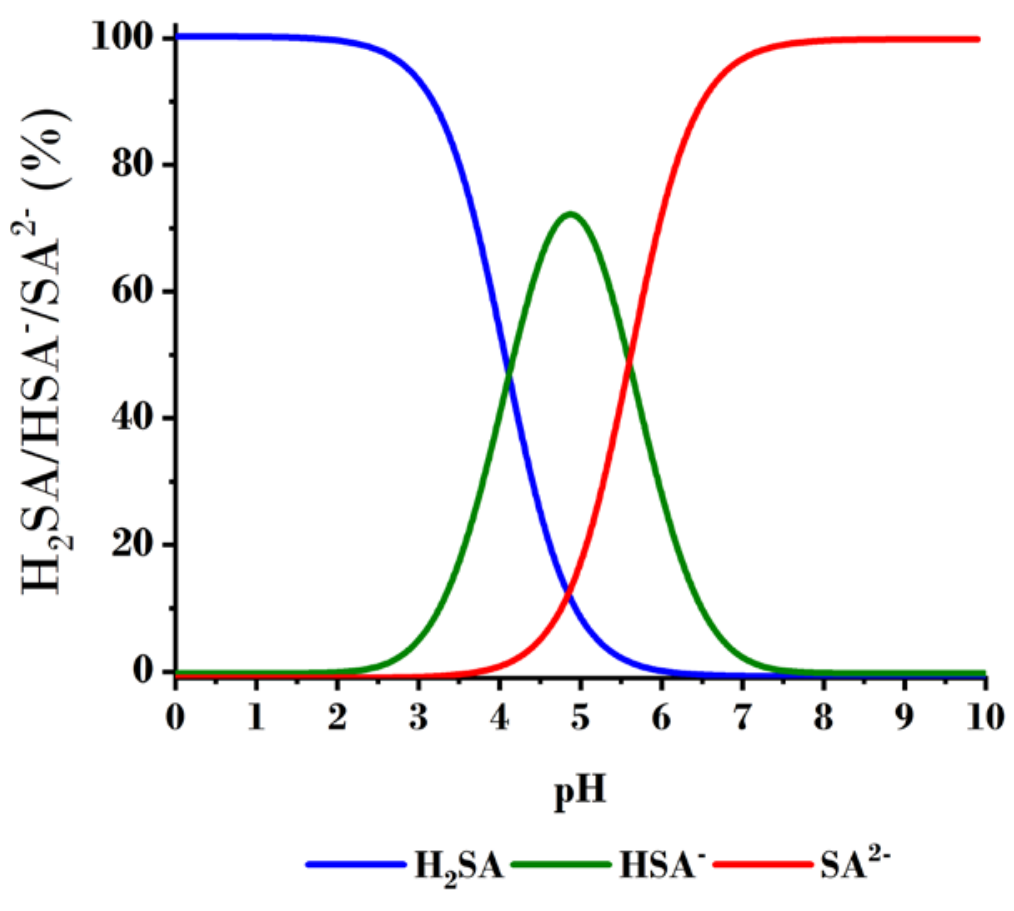

926 Figure 6. Effect of $\mathrm{pH}$ on succinic acid dissociation to form HAS- $\left(\mathrm{C}_{4} \mathrm{H}_{5} \mathrm{O}_{4}{ }^{-}\right)$and SA2-

$927\left(\mathrm{C}_{4} \mathrm{H}_{4} \mathrm{O}_{4}{ }^{2-}\right)$; the $\mathrm{pKa}_{1}=4.16, \mathrm{pKa}_{2}=5.6$ (Jansen \& van Gulik, 2014).

928 


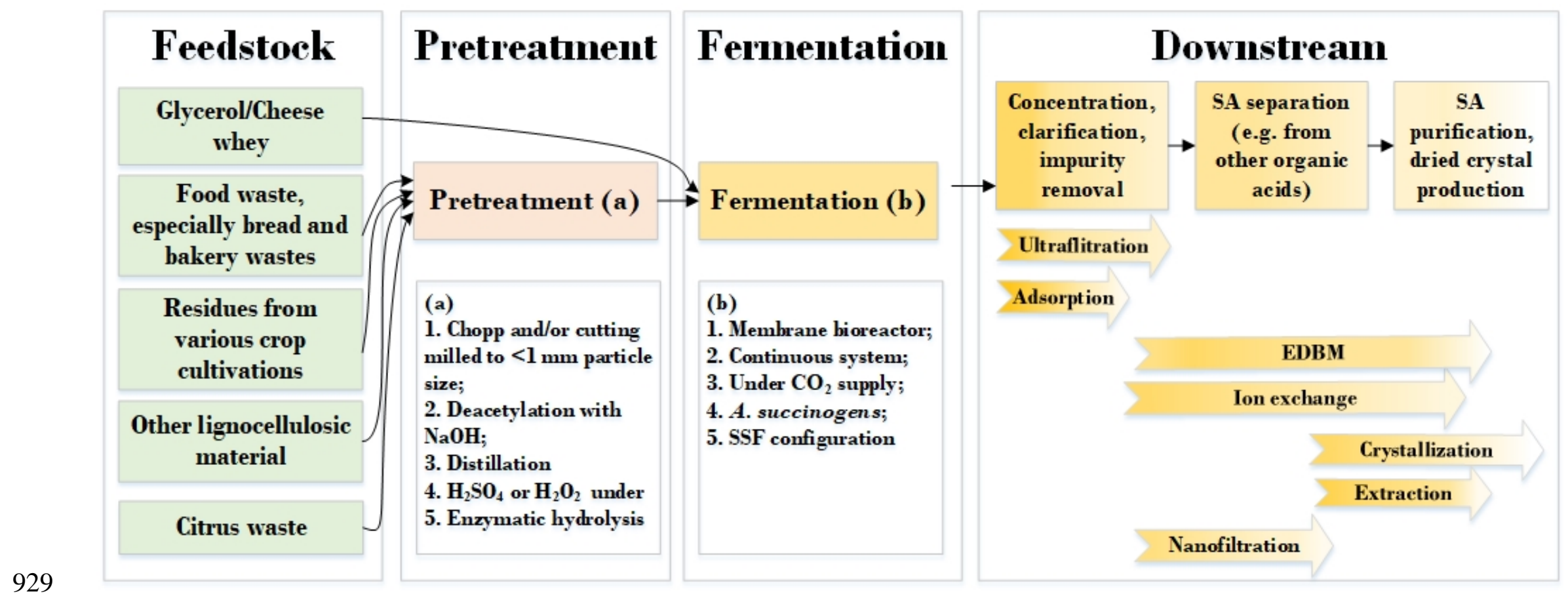

930 Figure 8. Generic process for succinic acid production listing the most relevant second generation feed-stocks, the proposed

931 pretreatments and fermentation conditions and the optimal range under which major separation techniques can operate. 


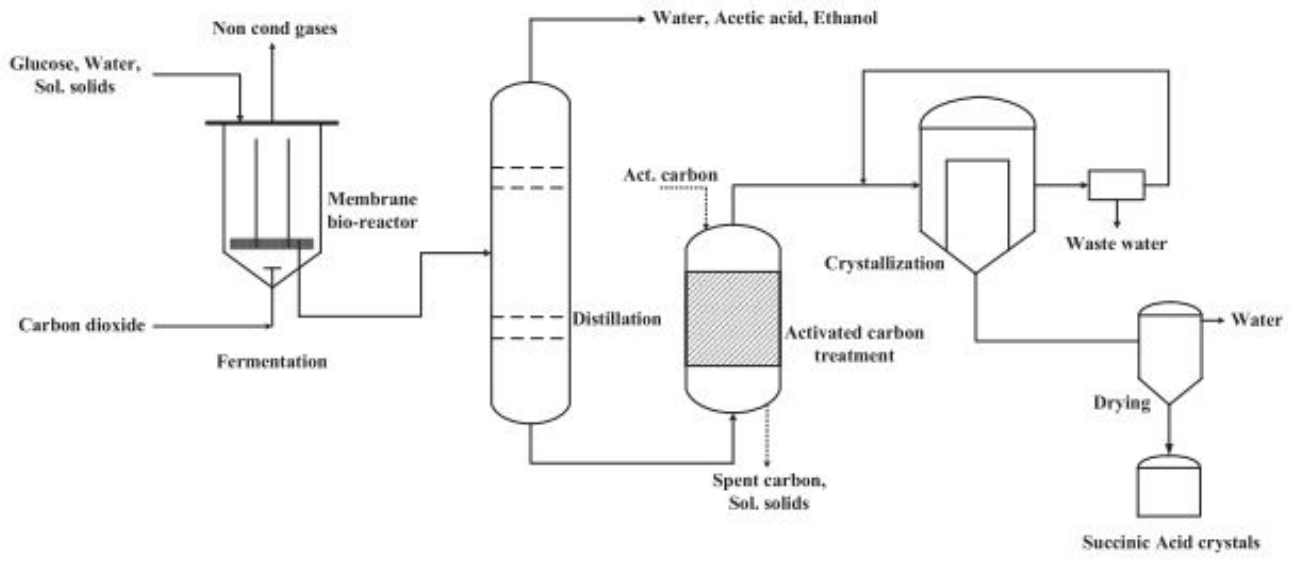

a) Flowsheet alternative 1

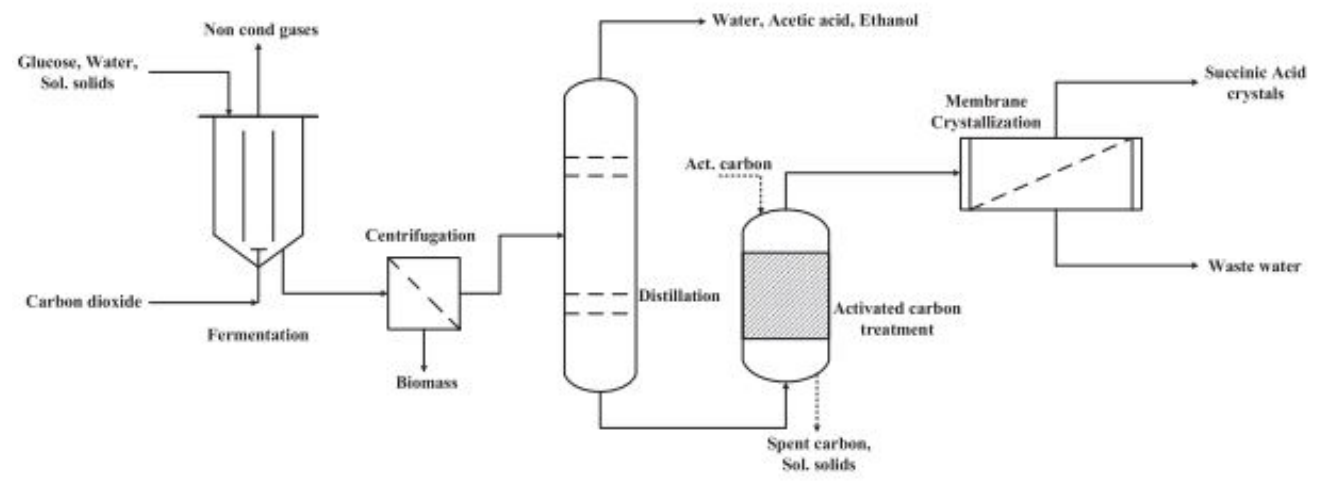

b) Flowsheet alternative 2

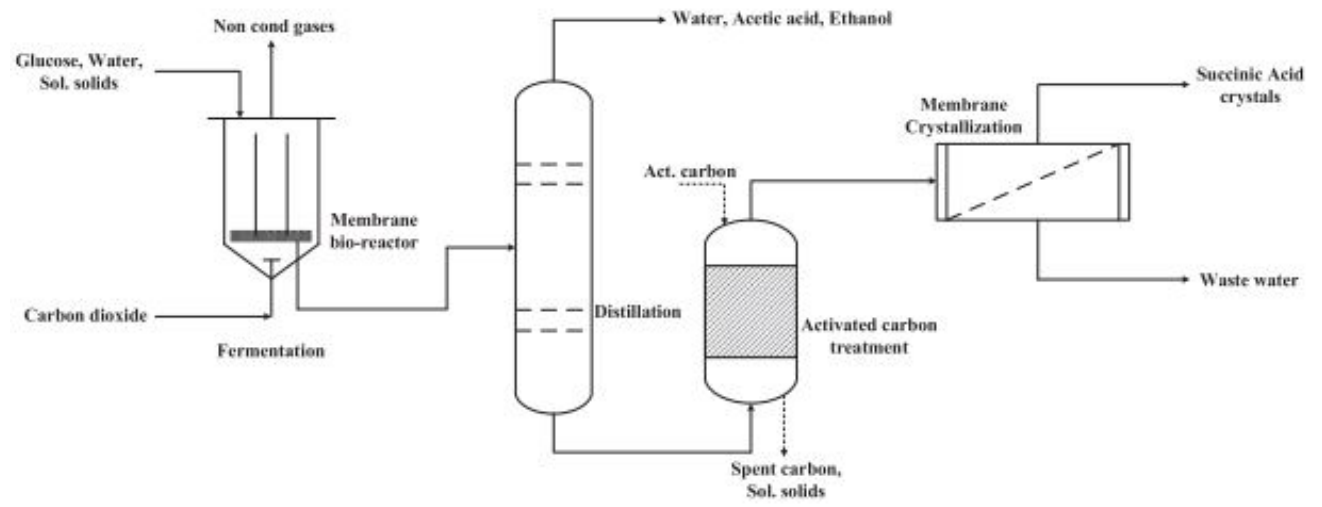

c) Flowsheet alternative 3

934 Figure 7. Generated alternative processes for the production of bio-based SA (with permission 935 from Garg et al. (2019). 
936 Table 1. Overview of the major industrial actors producing succinic acid (SA) from fermentation today, their presumed technologies

937 and resultant challenges.

\begin{tabular}{|c|c|c|c|c|c|c|c|c|}
\hline Company & $\begin{array}{l}\text { Capacity } \\
\text { (kt/year) }\end{array}$ & Operative & $\begin{array}{l}\text { Raw } \\
\text { material }\end{array}$ & $\begin{array}{l}\text { Fermentation/ } \\
\text { Microorganism }\end{array}$ & $\begin{array}{l}\text { Downstream } \\
\text { recovery }\end{array}$ & Potential problems/Challenges & Location & Ref. \\
\hline BioAmber $^{1}$ & $\begin{array}{l}\mathrm{t} / \mathrm{y} \\
\text { demo } \\
\text { plant }\end{array}$ & 2010 & $\begin{array}{l}\text { Wheat } \\
\text { glucose }\end{array}$ & E. coli & Electrodialysis & $\begin{array}{l}\text { - Electricity costs for EDBM } \\
\text { - Effect of sodium in } \\
\text { fermentation }\end{array}$ & $\begin{array}{l}\text { Pomacle, } \\
\text { France }\end{array}$ & $\begin{array}{l}\text { (EC-DGE, } \\
2015)\end{array}$ \\
\hline $\begin{array}{l}\text { BioAmber }^{1} \\
\text { Mitsui \& Co }\end{array}$ & $30-50$ & 2015 & $\begin{array}{l}\text { Corn } \\
\text { glucose }\end{array}$ & $\begin{array}{l}\text { Candida krusei } \\
\text { /pH 3, aerobic } \\
\text { batch }\end{array}$ & $\begin{array}{l}\mathrm{DAS}^{2}+ \\
\text { reactive } \\
\text { evaporation }\end{array}$ & & $\begin{array}{l}\text { Sarnia, } \\
\text { Canada }\end{array}$ & $\begin{array}{l}\text { (Cavani, } \\
\text { Albonetti, } \\
\text { Basile, \& } \\
\text { Gandini, 2016; } \\
\text { EC-DGE, } \\
\text { 2015; Finley et } \\
\text { al., 2013) }\end{array}$ \\
\hline $\begin{array}{l}\text { Biosuccinium } \\
\text { (Roquette) }\end{array}$ & 10 & 2012 & Starch/Sugar & $\begin{array}{l}\mathrm{pH} 3 \text {, dual phase } \\
\text { fed-batch/ } \\
\text { Recombinant } S \text {. } \\
\text { cerevisiae (by } \\
\text { DSM) }\end{array}$ & $\begin{array}{l}\text { Direct } \\
\text { separation of } \\
\text { SA }\end{array}$ & $\begin{array}{l}\text { - Effect of low pH on } \\
\text { fermentation performance. }\end{array}$ & $\begin{array}{l}\text { Cassano, } \\
\text { Spinola, Italy }\end{array}$ & $\begin{array}{l}\text { (EC-DGE, } \\
\text { 2015; Ferone } \\
\text { et al., 2019; } \\
\text { Jansen \& van } \\
\text { Gulik, 2014; } \\
\text { Nghiem et al., } \\
\text { 2017) }\end{array}$ \\
\hline Myriant & 14 & 2013 & $\begin{array}{l}\text { Glucose/ } \\
\text { Sugars }^{4}\end{array}$ & E. coli ${ }^{5}$ & $\begin{array}{l}\text { Ammonia } \\
\text { precipitation }\end{array}$ & $\begin{array}{l}\text {-SA recovery in di-ammonium } \\
\text { - Ammonia effect in fermentation }\end{array}$ & $\begin{array}{l}\text { Lake } \\
\text { providence, } \\
\text { Luisiana, } \\
\text { USA }\end{array}$ & $\begin{array}{l}\text { (EC-DGE, } \\
\text { 2015; Myriant, } \\
\text { 2019) }\end{array}$ \\
\hline $\begin{array}{l}\text { Succinity (joint } \\
\text { venture BASF } \\
\text { \& Corbion- } \\
\text { Purac) }\end{array}$ & 10 & 2014 & $\begin{array}{l}\text { Glycerol/ } \\
\text { Sugar/ } / \mathrm{CO}_{2}\end{array}$ & $\begin{array}{l}\text { Anaerobic fed- } \\
\text { batch/B. } \\
\text { succiniciproducens }\end{array}$ & $\begin{array}{l}\text { MgOH as } \\
\text { neutralizer } \\
\text { followed by } \\
\text { recycling }\end{array}$ & $\begin{array}{l}\text { - Dependency on two recycles in } \\
\text { process } \\
\text {-Cost and performance of } \mathrm{MgCl}_{2} \\
\text { cracking } \\
\text {-SA recovery in } \mathrm{MgCl}_{2} \text {-stream }\end{array}$ & $\begin{array}{l}\text { Montmelo, } \\
\text { Spain }\end{array}$ & $\begin{array}{l}\text { (BASF, 2014; } \\
\text { EC-DGE, } \\
\text { 2015; Pateraki } \\
\text { et al., 2016) }\end{array}$ \\
\hline
\end{tabular}

938 1. BioAmber is currently in CCAA proceedings (Companies’ Creditor Arrangement Act)(Blain, 2019)

939 2. DAS: diammonium succinate. 
940 3. The company has developed a recombined S. cerevisiae for co-production of ethanol and SA. It is not clear if this is the strain used in the plant.

941 4. The glucose is obtained from sorghum, while sugars are extracted from lignocellulosic biomasses.

942 5. The E. coli strain was specifically developed to produce succinic acid from lignocellulose-derived sugars.

943 Table 2. Summary of some pretreatment methods used in biorefinery with their advantages and disadvantages and their use for SA

944 production (Modified from Kumar et al., (2009)).

\begin{tabular}{|c|c|c|c|c|c|}
\hline $\begin{array}{l}\text { Pretreatment } \\
\text { method }\end{array}$ & Advantages & $\begin{array}{l}\text { Disadvantages and } \\
\text { limits }\end{array}$ & $\begin{array}{l}\text { Examples in } \\
\text { SA production }\end{array}$ & $\begin{array}{l}\text { Specific details on used } \\
\text { pretreatments/Notes }\end{array}$ & References \\
\hline \multirow[t]{2}{*}{$\begin{array}{l}\text { Steam } \\
\text { explosion }\end{array}$} & \multirow[t]{2}{*}{$\begin{array}{l}\text { Degradation of } \\
\text { hemicellulose and } \\
\text { lignin } \\
\text { transformation; cost- } \\
\text { effective }\end{array}$} & \multirow{2}{*}{$\begin{array}{l}\text { Partial destruction of } \\
\text { xylan and of the } \\
\text { lignin-carbohydrate } \\
\text { matrix; generation of } \\
\text { compounds inhibitory } \\
\text { to microorganisms. }\end{array}$} & $\begin{array}{l}\text { Oak and wood } \\
\text { chips }\end{array}$ & $\begin{array}{l}215 \circ \mathrm{C} \text { for } 3 \text { min in an } 81 \\
\text { exploder followed by } \\
\text { enzymatic hydrolysis at } 50{ }^{\circ} \mathrm{C} \\
\text { for } 3 \mathrm{~d} \text {. }\end{array}$ & $\begin{array}{l}\text { (Kim et al., 2004; } \\
\text { Lee, Lee, Hong, } \\
\text { Chang, et al., } \\
\text { 2003) }\end{array}$ \\
\hline & & & $\begin{array}{l}\text { Crop stalks } \\
\text { (including corn } \\
\text { and cotton) }\end{array}$ & $\begin{array}{l}10 \text { min at } 1.5 \mathrm{MPa} \text { then } \\
\text { filtration, dehydration, } \\
\text { explosion to } 1 \%(\mathrm{w} / \mathrm{v}) \\
\mathrm{NaOH} \text { and } 4 \%(\mathrm{v} / \mathrm{v}) \mathrm{H}_{2} \mathrm{O}_{2} \\
\text { for } 24 \mathrm{~h} \text { at the room } \\
\text { temperature, followed by } \\
\text { enzymatic pretreatment. }\end{array}$ & $\begin{array}{l}\text { (Q. Li, Yang, et al., } \\
\text { 2010) }\end{array}$ \\
\hline $\begin{array}{l}\text { Ammonia } \\
\text { Fiber } \\
\text { explosion }\end{array}$ & $\begin{array}{l}\text { Increase accessible } \\
\text { surface area, partial } \\
\text { removal of lignin and } \\
\text { hemicellulose, does } \\
\text { not produce } \\
\text { inhibitors for } \\
\text { downstream } \\
\text { processes. }\end{array}$ & $\begin{array}{l}\text { Not efficient for } \\
\text { lignin-rich biomass. }\end{array}$ & - & - & \\
\hline
\end{tabular}




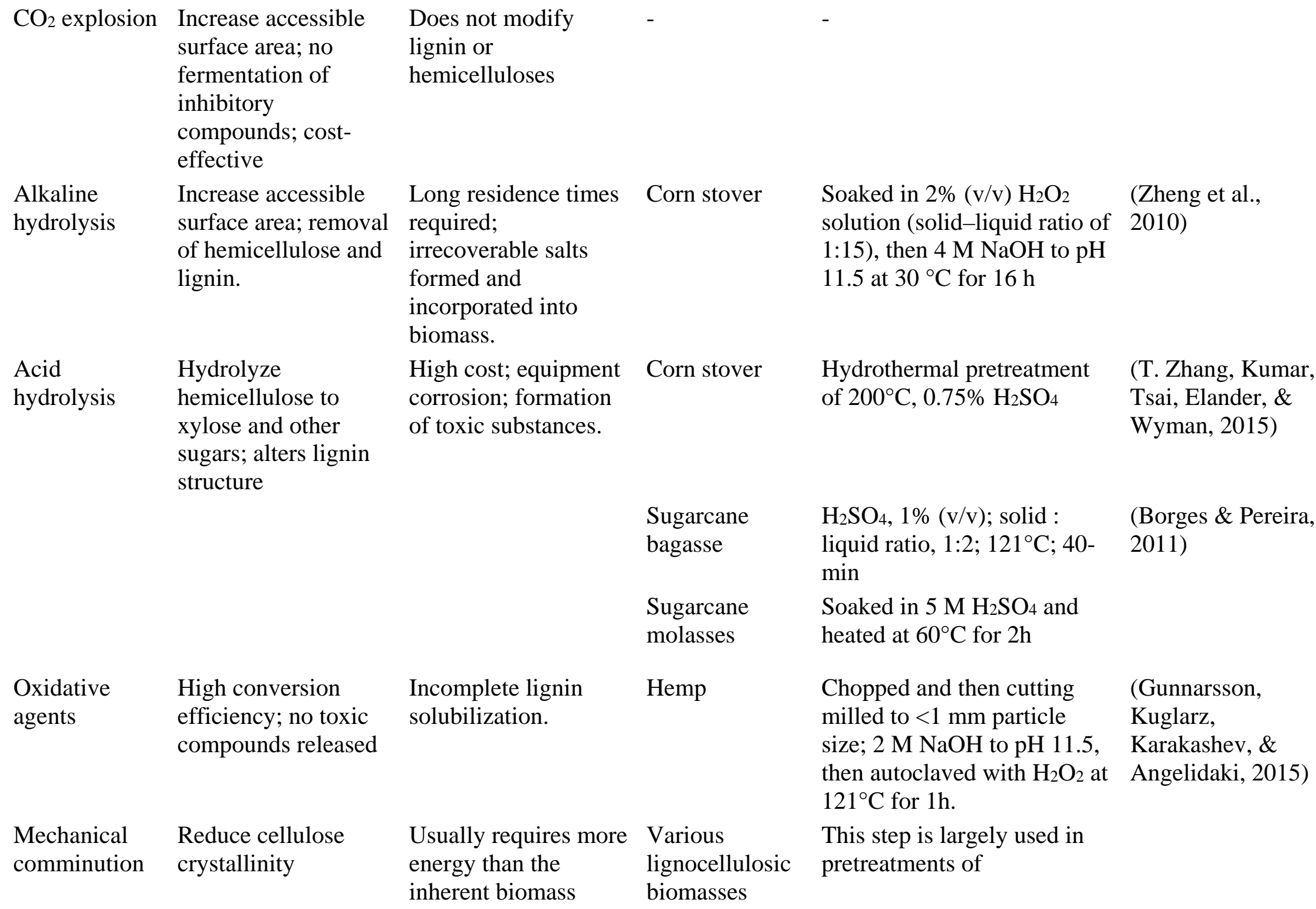

$\mathrm{CO}_{2}$ explosion Increase accessible

surface area; no

fermentation of

inhibitory

compounds; cost-

effective

Alkaline

hydrolysis

Increase accessible surface area; removal of hemicellulose and lignin.

$\begin{array}{ll}\text { Acid } & \text { Hydrolyze } \\ \text { hydrolysis } & \text { hemicellulose to } \\ & \text { xylose and other } \\ & \text { sugars; alters lignin } \\ & \text { structure }\end{array}$

Oxidative

High conversion agents

Mechanical

Reduce cellulose comminution

Does not modify

lignin or

hemicelluloses

Long residence times required; irrecoverable salts formed and incorporated into biomass.

High cost; equipment Corn stover corrosion; formation of toxic substances.

Sugarcane bagasse

Sugarcane molasses

Incomplete lignin solubilization.

compounds released

Usually requires more Various energy than the inherent biomass

Soaked in 2\% (v/v) $\mathrm{H}_{2} \mathrm{O}_{2} \quad$ (Zheng et al., solution (solid-liquid ratio of 2010) 1:15), then $4 \mathrm{M} \mathrm{NaOH}$ to $\mathrm{pH}$ 11.5 at $30{ }^{\circ} \mathrm{C}$ for $16 \mathrm{~h}$

Hydrothermal pretreatment of $200^{\circ} \mathrm{C}, 0.75 \% \mathrm{H}_{2} \mathrm{SO}_{4}$

(T. Zhang, Kumar, Tsai, Elander, \& Wyman, 2015)

$\mathrm{H}_{2} \mathrm{SO}_{4}, 1 \%(\mathrm{v} / \mathrm{v})$; solid :

(Borges \& Pereira, liquid ratio, $1: 2 ; 121^{\circ} \mathrm{C}$; 402011) min

Soaked in $5 \mathrm{M} \mathrm{H}_{2} \mathrm{SO}_{4}$ and heated at $60^{\circ} \mathrm{C}$ for $2 \mathrm{~h}$

\section{Hemp}

Chopped and then cutting milled to $<1 \mathrm{~mm}$ particle size; $2 \mathrm{M} \mathrm{NaOH}$ to $\mathrm{pH} 11.5$, then autoclaved with $\mathrm{H}_{2} \mathrm{O}_{2}$ at $121^{\circ} \mathrm{C}$ for $1 \mathrm{~h}$.

This step is largely used in lignocellulosic pretreatments of

(Gunnarsson,

Kuglarz,

Karakashev, \&

Angelidaki, 2015) crystallinity 


\begin{tabular}{|c|c|c|c|c|c|}
\hline & & $\begin{array}{l}\text { energy; high } \\
\text { greenhouse gas } \\
\text { emissions }{ }^{\mathrm{a}} \text {. }\end{array}$ & & $\begin{array}{l}\text { lignocellulosic biomasses } \\
\text { also for SA production. }\end{array}$ & \\
\hline Organosolv & $\begin{array}{l}\text { Hydrolyze lignin and } \\
\text { hemicelluloses }\end{array}$ & $\begin{array}{l}\text { Solvents need to be } \\
\text { drained from the } \\
\text { reactor, evaporated, } \\
\text { condensed, and } \\
\text { recycled; high cost }\end{array}$ & - & - & \\
\hline Biological & $\begin{array}{l}\text { Degrade lignin and } \\
\text { hemicelluloses; low } \\
\text { energy requirements; } \\
\text { less corrosion issues }\end{array}$ & $\begin{array}{l}\text { Hydrolysis rate is } \\
\text { very low. Cellulosic } \\
\text { enzymes are } \\
\text { expensive. }\end{array}$ & $\begin{array}{l}\text { Various } \\
\text { lignocellulosic } \\
\text { biomasses }\end{array}$ & $\begin{array}{l}\text { Many studies on SA } \\
\text { production from } \\
\text { lignocellulosic matter use an } \\
\text { enzymatic step in the } \\
\text { pretreatment process. }\end{array}$ & $\begin{array}{l}\text { (Gunnarsson et al., } \\
\text { 2015; Kim et al., } \\
\text { 2004; Lee, Lee, } \\
\text { Hong, Chang, et } \\
\text { al., 2003; Q. Li, } \\
\text { Yang, et al., 2010; } \\
\text { Salvachúa et al., } \\
\text { 2016) }\end{array}$ \\
\hline
\end{tabular}

946 Table 3. Major advantages and disadvantages of the two most relevant configurations for SA production (SHF and SSF) and the

947 operational techniques (batch, fed-batch and continuous).

\begin{tabular}{lll}
\hline $\begin{array}{l}\text { Reactor's } \\
\text { configuration }\end{array}$ & Advantages & Disadvantages \\
SHF & $\begin{array}{l}\text { Optimization of hydrolysis and fermentation processes. } \\
\text { Higher control of fermentation inhibitors and potential } \\
\text { reduction of downstream processes. }\end{array}$ & $\begin{array}{l}\text { High capital and operative costs. Low yield with E. } \\
\text { coli on glucose, galactose and sucrose (Akhtar et al., } \\
\text { 2014). }\end{array}$ \\
& $\begin{array}{l}\text { Simple; cost-effective since low capital cost and low } \\
\text { energy consumption; reduced substrate toxicity (Zheng } \\
\text { et al., 2010). }\end{array}$ & $\begin{array}{l}\text { Softwood lignocellulosic biomass contains 10\%. } \\
\text { silicon, which is toxic for enzymes in SSF (Akhtar et } \\
\text { al., 2014). }\end{array}$ \\
\hline
\end{tabular}




\begin{tabular}{|c|c|c|}
\hline \multicolumn{3}{|l|}{$\begin{array}{l}\text { Operational } \\
\text { techniques }\end{array}$} \\
\hline Batch & Simple to operate; high yield & $\begin{array}{l}\text { Low production rate; repeated inoculation and } \\
\text { sterilization times; low biomass concentration which } \\
\text { leads to big reactor's volume required. }\end{array}$ \\
\hline Fed-batch & $\begin{array}{l}\text { Simple; efficient for toxic feed-stocks; biomass can be } \\
\text { concentrated, thus reduced reactor's volume are needed. }\end{array}$ & $\begin{array}{l}\text { Reduced production rate; repeated inoculation and } \\
\text { sterilization times. }\end{array}$ \\
\hline Continuous & $\begin{array}{l}\text { High production rate; high yield with cell } \\
\text { immobilization; biomass concentration and thus reduced } \\
\text { reactors volume. }\end{array}$ & $\begin{array}{l}\text { Complex to operate; low yield if no cell } \\
\text { immobilization applied. }\end{array}$ \\
\hline
\end{tabular}

Table 4. Fermentation-based succinic acid (SA) production from different carbon sources: the microorganisms, the substrates, the final

949 Table 4. Fermentation-based succinic acid (SA) produc
950 SA titer, production rate and SA yield are presented.

\begin{tabular}{|c|c|c|c|c|c|c|c|}
\hline Raw material & $\begin{array}{l}\text { Intermediate } \\
\text { platform }\end{array}$ & Type of fermentation & Microorganism & $\begin{array}{l}\text { Titer } \\
\text { (g/L) }\end{array}$ & $\begin{array}{l}\text { Productivity } \\
\text { (g/l/h) }\end{array}$ & Yield & Ref. \\
\hline \multicolumn{8}{|c|}{$\begin{array}{l}\text { Pure carbon sources and first } \\
\text { generation biomasses }\end{array}$} \\
\hline & Glucose & Dual-phase batch & E. coli (Tang1528) & 89.4 & 1.24 & $83.0 \mathrm{wt} \%$ & $\begin{array}{l}\text { (Yu et al., } \\
\text { 2016) }\end{array}$ \\
\hline & Glucose & $\begin{array}{l}\text { Micro-aerobic, fed- } \\
\text { batch with membrane } \\
\text { for cell recycling }\end{array}$ & $\begin{array}{l}\text { C. glutamicum ( } \Delta \text { ldhA- } \\
\text { pCRA717) }\end{array}$ & 146 & 3.2 & $92.0 \mathrm{wt} \%$ & $\begin{array}{l}\text { (Okino et al., } \\
\text { 2008) }\end{array}$ \\
\hline & Glucose & Anaerobic batch & A. succinogenes & $39.4 \pm 0.7$ & - & $79.3 \pm 1.5 \mathrm{wt} \%$ & $\begin{array}{l}\text { (Liu et al., } \\
\text { 2008) }\end{array}$ \\
\hline & Glucose & $\begin{array}{l}\text { Continuous with } \\
\text { immobilized cells }\end{array}$ & A. succinogenes & $\begin{array}{l}12.0 \text { at } \\
\mathrm{D}=0.56 \mathrm{~h}^{-1}\end{array}$ & 6.35 & $69 \pm 2 \mathrm{wt} \%$ & $\begin{array}{l}\text { (van Heerden } \\
\text { \& Nicol, 2013) }\end{array}$ \\
\hline & Glucose & $\begin{array}{l}\text { Continuous with } \\
\text { immobilized cells }\end{array}$ & A. succinogenes & $\begin{array}{l}18.0 \text { at } \\
\mathrm{D}=0.5 \mathrm{~h}^{-1}\end{array}$ & 9.2 & $70 \mathrm{wt} \%$ & $\begin{array}{l}\text { (Brink \& Nicol, } \\
\text { 2014) }\end{array}$ \\
\hline & Sucrose & Anaerobic batch & E. flavescens & $2.82 \pm 0.12$ & - & - & $\begin{array}{l}\text { (Agarwal et al., } \\
\text { 2007) }\end{array}$ \\
\hline
\end{tabular}




\begin{tabular}{|c|c|c|c|c|c|c|}
\hline Sucrose & Fed-batch & $\begin{array}{l}\text { A. succinogenes } \\
\text { (NJ113) }\end{array}$ & 60.4 & 2.16 & $83.0 \mathrm{wt} \%$ & $\begin{array}{l}\text { (Jiang et al., } \\
\text { 2014) }\end{array}$ \\
\hline Sucrose & Anaerobic batch & A. succinogenes & $40.3 \pm 0.8$ & - & $81.4 \pm 1.6 w t \%$ & $\begin{array}{l}\text { (Liu et al., } \\
\text { 2008) }\end{array}$ \\
\hline Fructose & Anaerobic batch & E. flavescens & $0.93 \pm 0.04$ & - & - & $\begin{array}{l}\text { (Agarwal et al., } \\
\text { 2007) }\end{array}$ \\
\hline Fructose & Anaerobic batch & A. succinogenes & $1.2 \pm 0.4$ & - & $78.6 \pm 1.8 \mathrm{wt} \%$ & $\begin{array}{l}\text { (Liu et al., } \\
\text { 2008) }\end{array}$ \\
\hline Maltose & Anaerobic batch & E. flavescens & $1.3 \pm 0.07$ & - & - & $\begin{array}{l}\text { (Agarwal et al., } \\
\text { 2007) }\end{array}$ \\
\hline Xylose & Anaerobic batch & E. flavescens & $0.52 \pm 0.02$ & - & - & $\begin{array}{l}\text { (Agarwal et al., } \\
\text { 2007) }\end{array}$ \\
\hline Xylose & Anaerobic batch & A. succinogenes & $32.6 \pm 1.2$ & - & $76.9 \pm 2.7 w t \%$ & $\begin{array}{l}\text { (Liu et al., } \\
\text { 2008) }\end{array}$ \\
\hline Lactose & Anaerobic batch & E. flavescens & $2.1 \pm 0.09$ & - & - & $\begin{array}{l}\text { (Agarwal et al., } \\
\text { 2007) }\end{array}$ \\
\hline Galactose & Anaerobic batch & E. flavescens & $0.66 \pm 0.03$ & - & - & $\begin{array}{l}\text { (Agarwal et al., } \\
\text { 2007) }\end{array}$ \\
\hline Sorbitol & Anaerobic batch & E. flavescens & $0.61-14.8$ & - & - & $\begin{array}{l}\text { (Agarwal et al., } \\
\text { 2007) }\end{array}$ \\
\hline Mannitol & Anaerobic batch & E. flavescens & $0.21 \pm 0.03$ & - & - & $\begin{array}{l}\text { (Agarwal et al., } \\
\text { 2007) }\end{array}$ \\
\hline Rhamnose & Anaerobic batch & E. flavescens & $0.24 \pm 0.04$ & - & - & $\begin{array}{l}\text { (Agarwal et al., } \\
\text { 2007) }\end{array}$ \\
\hline Arabinose & Anaerobic batch & E. flavescens & $0.13 \pm 0.04$ & - & - & $\begin{array}{l}\text { (Agarwal et al., } \\
\text { 2007) }\end{array}$ \\
\hline Glycerol & Anaerobic batch & $\begin{array}{l}\text { A. succinogenes (ATCC } \\
\text { 55618) }\end{array}$ & $24.39 \pm 4.5$ & $2.13 \pm 0.56$ & $95 \pm 20 \mathrm{wt} \%$ & $\begin{array}{l}\text { (Carvalho et } \\
\text { al., 2014) }\end{array}$ \\
\hline Glycerol & Anaerobic fed-batch & $\begin{array}{l}\text { A. succinogenes (ATCC } \\
\text { 55618) }\end{array}$ & 49.62 & 0.96 & $64 \mathrm{wt} \%$ & $\begin{array}{l}\text { (Carvalho et } \\
\text { al., 2014) }\end{array}$ \\
\hline Glycerol & Anaerobic batch & E. flavescens & $1.3 \pm 0.07$ & - & - & $\begin{array}{l}\text { (Agarwal et al., } \\
\text { 2007) }\end{array}$ \\
\hline $\begin{array}{l}\text { GAX (Glucose, } \\
\text { Arabinose, Xylose) }\end{array}$ & $\begin{array}{l}\text { Continuous with } \\
\text { immobilized cells }\end{array}$ & A. succinogenes & $\begin{array}{l}20.5 \text { at } \mathrm{D}= \\
0.7 \mathrm{~h}^{-1}\end{array}$ & 15.0 & 0.56 & $\begin{array}{l}\text { (Ferone et al., } \\
\text { 2018) }\end{array}$ \\
\hline
\end{tabular}




\begin{tabular}{|c|c|c|c|c|c|c|c|}
\hline \multicolumn{2}{|l|}{ Starch } & Anaerobic batch & E. flavescens & $0.13 \pm 0.006$ & - & - & $\begin{array}{l}\text { (Agarwal et al., } \\
\text { 2007) }\end{array}$ \\
\hline \multicolumn{2}{|l|}{ Wheat } & SmF-based ${ }^{1}$ & $\begin{array}{l}\text { A. succinogenes } \\
\text { (ATCC 55618) }\end{array}$ & 16 & 0.31 & $19 \mathrm{wt} \%$ & $\begin{array}{l}\text { (Du et al., } \\
\text { 2007) }\end{array}$ \\
\hline \multicolumn{2}{|l|}{ Wheat } & Solid state fermentation & $\begin{array}{l}\text { A. succinogenes } \\
\text { (ATCC 55618) }\end{array}$ & $64.2 \pm 1.0$ & $1.19 \pm 0.05$ & $40 \mathrm{wt} \%$ & $\begin{array}{l}\text { (Du et al., } \\
\text { 2008) }\end{array}$ \\
\hline \multicolumn{8}{|c|}{ Second generation biomass } \\
\hline Arundo donax & $\begin{array}{l}\text { Glucose } \\
\text { Xylose }\end{array}$ & Anaerobic batch & $\begin{array}{l}\text { B. succiniciproducens } \\
\text { BPP7 }\end{array}$ & 17 & 0.35 & $\begin{array}{l}\text { 54\% (g SA/g } \\
\text { glucose+xylose) }\end{array}$ & $\begin{array}{l}\text { (Cimini et al., } \\
\text { 2016) }\end{array}$ \\
\hline Cane molasses & & Anaerobic batch & A. succinogenes & 46.4 & 0.97 & $\begin{array}{l}79.5 \% \text { (g SA/g } \\
\text { glucose) }\end{array}$ & $\begin{array}{l}\text { (Liu et al., } \\
\text { 2008) }\end{array}$ \\
\hline Cane molasses & & Anaerobic fed-batch & A. succinogenes & 55.2 & 1.15 & $\begin{array}{l}94 \% \text { (g SA/g } \\
\text { glucose) }\end{array}$ & $\begin{array}{l}\text { (Liu et al., } \\
\text { 2008) }\end{array}$ \\
\hline Cane molasses & & Anaerobic batch & E. flavescens & $0.5 \pm 0.02$ & - & - & $\begin{array}{l}\text { (Agarwal et al., } \\
\text { 2007) }\end{array}$ \\
\hline Cane bagasse & Hemicellulose & Anaerobic batch & $\begin{array}{l}\text { A. succinogenes (CIP } \\
\text { 106512) }\end{array}$ & 22.5 & 1.01 & $43 \mathrm{wt} \%$ & $\begin{array}{l}\text { (Borges \& } \\
\text { Pereira, 2011) }\end{array}$ \\
\hline Cane bagasse & & Anaerobic batch & $\begin{array}{l}\text { A. succinogenes } \\
\text { (CСTCCM2012036) }\end{array}$ & 120 & 1.65 & $80.5 \mathrm{wt} \%$ & $\begin{array}{l}\text { (Chen et al., } \\
\text { 2016) }\end{array}$ \\
\hline Cane bagasse & & Anaerobic batch & E. coli (BA305) & 83 & - & $87.0 \mathrm{wt} \%$ & $\begin{array}{l}\text { (Liang et al., } \\
\text { 2013) }\end{array}$ \\
\hline $\begin{array}{l}\text { Wheat milling } \\
\text { by-products }\end{array}$ & & Solid state fermentation & $\begin{array}{l}\text { A. succinogenes } \\
\text { (ATCC55618) }\end{array}$ & 62.1 & 0.91 & $8.7 \mathrm{wt} \%$ & $\begin{array}{l}\text { (Dorado et al., } \\
\text { 2009) }\end{array}$ \\
\hline Wheat straw $^{2}$ & & Anaerobic batch & $\begin{array}{l}\text { F. succinogenes S85 } \\
\text { (ATCC 19169) }\end{array}$ & 2.02 & $\approx 22.5$ & $\approx 3 \mathrm{wt} \%$ & $\begin{array}{l}\text { (Q. Li et al., } \\
\text { 2010) }\end{array}$ \\
\hline $\begin{array}{l}\text { Corn straw } \\
\text { hydrolysate }\end{array}$ & Glucose, Xylose & Anaerobic fed-batch & $\begin{array}{l}\text { A. succinogenes } \\
\text { (CGMCC1593) }\end{array}$ & 53.2 & 1.21 & $82.5 \mathrm{wt} \%$ & $\begin{array}{l}\text { (Zheng et al., } \\
\text { 2009) }\end{array}$ \\
\hline $\begin{array}{l}\text { Corn straw } \\
\text { hydrolysate }\end{array}$ & Glucose, Xylose & Anaerobic batch & $\begin{array}{l}\text { A. succinogenes } \\
\text { (CGMCC1593) }\end{array}$ & 45.5 & 0.95 & $80.7 \mathrm{wt} \%$ & $\begin{array}{l}\text { (Zheng et al., } \\
\text { 2009) }\end{array}$ \\
\hline Corn stalk & & Anaerobic batch & A. succinogenes (BE-1) & 15.8 & 0.56 & $\begin{array}{l}66.0 \% \text { (g SA/g total } \\
\text { sugars) }\end{array}$ & $\begin{array}{l}\text { (Q. Li, Yang, et } \\
\text { al., 2010) }\end{array}$ \\
\hline Corn stover & & Anaerobic batch & $\begin{array}{l}\text { A. succinogenes } 130 Z \\
\text { (ATCC 55618) }\end{array}$ & 42.8 & 1.51 & $\begin{array}{l}0.74 \% \text { (g SA/g total } \\
\text { sugars) }\end{array}$ & $\begin{array}{l}\text { (Salvachúa et } \\
\text { al., 2016) }\end{array}$ \\
\hline
\end{tabular}




\begin{tabular}{|c|c|c|c|c|c|c|}
\hline Whey & Anaerobic fed-batch & A. succiniciproducens & 24.0 & 2.1 & $72.0 \mathrm{wt} \%$ & $\begin{array}{l}\text { (Samuelov et } \\
\text { al., 1999) }\end{array}$ \\
\hline Bread waste & Anaerobic batch & $\begin{array}{l}\text { A. succinogenes (ATCC } \\
55618 \text { ) }\end{array}$ & 47.3 & 1.12 & $55 \mathrm{wt} \%$ & $\begin{array}{l}\text { (Leung et al., } \\
\text { 2012) }\end{array}$ \\
\hline Bakery waste & Solid state fermentation & A. succinogenes & $\begin{array}{l}24.8^{(3)} \\
31.7^{(5)}\end{array}$ & $\begin{array}{l}0.79^{(3)} \\
0.87^{(5)}\end{array}$ & $\begin{array}{l}28 \mathrm{wt} \%{ }^{(4)} \\
35 \mathrm{wt}^{(5)}\end{array}$ & $\begin{array}{l}\text { (A. Y. Z. } \\
\text { Zhang et al., } \\
\text { 2013) }\end{array}$ \\
\hline \multicolumn{7}{|l|}{ Third generation biomass } \\
\hline \multirow[t]{2}{*}{$\begin{array}{l}\text { Macroalgae } \\
\text { L. japonica }\end{array}$} & Dual-phase batch & E. coli (BS002) & $\begin{array}{l}14.32 \pm \\
0.09\end{array}$ & - & $\begin{array}{l}1.39 \pm 0.01 \text { (mol } \\
\mathrm{SA} / \mathrm{mol} \text { total sugars) }\end{array}$ & $\begin{array}{l}\text { (Bai et al., } \\
\text { 2015) }\end{array}$ \\
\hline & Dual-phase batch & E. coli (BS002) & $9.86 \pm 0.48$ & - & $\begin{array}{l}1.01 \pm 0.05 \text { (mol } \\
\mathrm{SA} / \mathrm{mol} \text { total sugars) }\end{array}$ & $\begin{array}{l}\text { (Bai et al., } \\
\text { 2015) }\end{array}$ \\
\hline $\begin{array}{r}\text { Macroalgae } \\
\text { L. digitata }\end{array}$ & Anaerobic batch & $\begin{array}{l}\text { A. succinogenes } 130 \mathrm{Z} \\
\text { (DSM 22257) }\end{array}$ & - & 0.50 & $\begin{array}{l}86.49 \% \text { (g SA/g total } \\
\text { sugars) }\end{array}$ & $\begin{array}{l}\text { (Alvarado- } \\
\text { Morales et al., } \\
\text { 2015) }\end{array}$ \\
\hline
\end{tabular}

951

952 1. Submerged Fermentation

953 2. Not pretreated

954 3. Pretreated

955 4. From cake waste

956 5. From pastry waste 
Agarwal, L., Isar, J., Meghwanshi, G. K., \& Saxena, R. K. (2007). Influence of environmental and nutritional factors on succinic acid production and enzymes of reverse tricarboxylic acid cycle from Enterococcus flavescens. Enzyme and Microbial Technology, 40(4), 629636. https://doi.org/10.1016/j.enzmictec.2006.05.019

Akhtar, J., Idris, A., \& Abd. Aziz, R. (2014). Recent advances in production of succinic acid from lignocellulosic biomass. Applied Microbiology and Biotechnology, 98(3), 987-1000. https://doi.org/10.1007/s00253-013-5319-6

Alexandri, M., Vlysidis, A., Papapostolou, H., Tverezovskaya, O., Tverezovskiy, V., Kookos, I. K., \& Koutinas, A. (2019). Downstream separation and purification of succinic acid from fermentation broths using spent sulphite liquor as feedstock. Separation and Purification Technology, 209(January 2018), 666-675. https://doi.org/10.1016/j.seppur.2018.08.061

Alvarado-Morales, M., Gunnarsson, I. B., Fotidis, I. A., Vasilakou, E., Lyberatos, G., \&

Andersson, C., Hodge, D., Berglund, K. A., \& Rova, U. (2007). Effect of different carbon sources on the production of succinic acid using metabolically engineered Escherichia coli. Biotechnology Progress, 23(2), 381-388. https://doi.org/10.1021/bp060301y C. (2008). Production of Energy from Biomass. In J. H. Clark \& F. E. I. Deswarte (Eds.), Introduction to Chemicals from Biomass. York, UK: John Wiley \& Sons. production of succinic acid from macroalgae hydrolysate by metabolically engineered Escherichia coli. Bioresource Technology, 185, 56-61. https://doi.org/10.1016/j.biortech.2015.02.081

BASF. (2014). Succinity produces first commercial quantities of biobased succinic acid. 
Retrieved January 17, 2019, from https://www.basf.com/global/en/media/news-

Beauprez, J. J., De Mey, M., \& Soetaert, W. K. (2010). Microbial succinic acid production: Natural versus metabolic engineered producers. Process Biochemistry, 45(7), 1103-1114. https://doi.org/10.1016/j.procbio.2010.03.035

Bechthold, I., Bretz, K., Kabasci, S., Kopitzky, R., \& Springer, A. (2008). Succinic acid: A new platform chemical for biobased polymers from renewable resources. Chemical Engineering and Technology, 31(5), 647-654. https://doi.org/10.1002/ceat.200800063

Blain, P. (2019). BioAmber Inc., Bioamber Canada Inc. \& Bioamber Sarnia Inc. Retrieved February 27, 2019, from https://www.pwc.com/ca/en/services/insolvencyassignments/bioamber.html

Borges, E. R., \& Pereira, N. (2011). Succinic acid production from sugarcane bagasse

Borzani, W. (2006). Batch ethanol fermentation: The correlation between the fermentation 1002 1003 1004

Bradfield, M. F. A., Mohagheghi, A., Salvachúa, D., Smith, H., Black, B. A., Dowe, N., ... efficiency and the biomass initial concentration depends on what is considered as produced ethanol. Brazilian Journal of Microbiology, 37, 87-89. https://doi.org/10.1590/S1517-

\section{6}

1013 hemicellulose hydrolysate by Actinobacillus succinogenes. Journal of Industrial Microbiology and Biotechnology, 38(8), 1001-1011. https://doi.org/10.1007/s10295-0100874-7 Nicol, W. (2015). Continuous succinic acid production by Actinobacillus succinogenes on xylose-enriched hydrolysate. Biotechnology for Biofuels, 8(1), 181. https://doi.org/10.1186/s13068-015-0363-3

Bradfield, M. F. A., \& Nicol, W. (2016). The pentose phosphate pathway leads to enhanced succinic acid flux in biofilms of wild-type Actinobacillus succinogenes. Applied Microbiology and Biotechnology, 100(22), 9641-9652. https://doi.org/10.1007/s00253-0167763-6

Brink, H. G., \& Nicol, W. (2014). Succinic acid production with Actinobacillus succinogenes: 
1014

1015

1016

1017

1018

1019

1020

1021

1022

1023

1024

1025

1026

1027

1028

1029

1030

1031

1032

1033

1034

1035

1036

1037

1038

1039

1040

1041

Rate and yield analysis of chemostat and biofilm cultures. Microbial Cell Factories, 13(1), 1-12. https://doi.org/10.1186/s12934-014-0111-6

Brunklaus B, Rex E, Carlsson E, B. J. (2018). The future of Swedish food waste: An environmental assessment of existing and prospective valorization techniques. Journal of Cleaner Production., 202, 1-10. https://doi.org/https://doi.org/10.1016/j.jclepro.2018.07.240

Buchner, B., Fischler, C., Gustafson, E., Reilly, J., Riccardi, G., Ricordi, C., \& Veronesi, U. (2012). Food waste: causes, impacts and proposals. Barilla Center for Food \& Nutrition. https://doi.org/45854585

Cao, W., Wang, Y., Luo, J., Yin, J., Xing, J., \& Wan, Y. (2018a). Effectively converting carbon dioxide into succinic acid under mild pressure with Actinobacillus succinogenes by an integrated fermentation and membrane separation process. Bioresource Technology, 266(May), 26-33. https://doi.org/10.1016/j.biortech.2018.06.016

Cao, W., Wang, Y., Luo, J., Yin, J., Xing, J., \& Wan, Y. (2018b). Succinic acid biosynthesis from cane molasses under low $\mathrm{pH}$ by Actinobacillus succinogenes immobilized in luffa sponge matrices. Bioresource Technology, 268(May), 45-51. https://doi.org/10.1016/j.biortech.2018.06.075

Carvalho, M., Matos, M., Roca, C., \& Reis, M. A. M. (2014). Succinic acid production from glycerol by Actinobacillus succinogenes using dimethylsulfoxide as electron acceptor. New Biotechnology, 31(1), 133-139. https://doi.org/10.1016/j.nbt.2013.06.006

Carvalho, M., Roca, C., \& Reis, M. A. M. (2016). Improving succinic acid production by Actinobacillus succinogenes from raw industrial carob pods. Bioresource Technology, 218, 491-497. https://doi.org/10.1016/j.biortech.2016.06.140

Cavani, F., Albonetti, S., Basile, F., \& Gandini, A. (Eds.). (2016). Chemicals and Fuels from Bio-Based Building Blocks (Vol. 2). https://doi.org/10.1016/j.focat.2016.06.047

Chaiklahan, R., Chirasuwan, N., Loha, V., Tia, S., \& Bunnag, B. (2011). Bioresource Technology Separation and purification of phycocyanin from Spirulina sp . using a membrane process. Bioresource Technology, 102(14), 7159-7164. 
1043 Chandel, A. K., Garlapati, V. K., Singh, A. K., Antunes, F. A. F., \& da Silva, S. S. (2018). The 1044 path forward for lignocellulose biorefineries: Bottlenecks, Solutions, and perspective on 1045 commercialization. Bioresource Technology, (April), 0-1.

1046 https://doi.org/10.1016/j.biortech.2018.06.004

1047 Chatterjee, R., Millard, C. S., Champion, K., Clark, D. P., \& Donnelly, M. I. (2001). Mutation of 1048 the ptsG Gene Results in Increased Production of Succinate in Fermentation of Glucose by 1049 1050

1051 Chen, P., Tao, S., \& Zheng, P. (2016). Efficient and repeated production of succinic acid by 1052 turning sugarcane bagasse into sugar and support. Bioresource Technology, 211, 406-413. $1053 \quad$ https://doi.org/10.1016/j.biortech.2016.03.108

1054 Cheng, K.-K., Zhao, X.-B., Zeng, J., \& Zhang, J.-A. (2012). Biotechnological production of 1055 succinic acid: current state and perspectives. Biofuels, Bioproducts and Biorefining, 6(3), 1056 302-318. https://doi.org/10.1002/bbb.1327

1057 Cheng, K. K., Zhao, X. B., Zeng, J., Wu, R. C., Xu, Y. Z., Liu, D. H., \& Zhang, J. A. (2012). 1058 Downstream processing of biotechnological produced succinic acid. Applied Microbiology 1059

1060 Cherubini, F. (2010). The biorefinery concept: Using biomass instead of oil for producing energy 1061 and chemicals. Energy Conversion and Management, 51(7), 1412-1421. 1062 https://doi.org/10.1016/J.ENCONMAN.2010.01.015

1063 Choi, J. H., Fukushi, K., \& Yamamoto, K. (2008). A study on the removal of organic acids from 1064 wastewaters using nanofiltration membranes. Separation and Purification Technology, 1065 59(1), 17-25. https://doi.org/10.1016/j.seppur.2007.05.021

1066 Cimini, D., Argenzio, O., D’Ambrosio, S., Lama, L., Finore, I., Finamore, R., ... Schiraldi, C. 1067 (2016). Production of succinic acid from Basfia succiniciproducens up to the pilot scale 1068 from Arundo donax hydrolysate. Bioresource Technology, 222, 355-360.

1069 https://doi.org/10.1016/j.biortech.2016.10.004 
1070 Cok, B., Ioannis, T., Alexander L., R., \& Martin K., P. (2013). Succinic acid production derived from carbohydrates: An energy and greenhouse gas assessment of a platform chemical toward a bio-based economy. Biofuels, Bioproducts and Biorefining, 16-29. https://doi.org/10.1002/bbb.1427

Cukalovic, A., \& Stevens, C. V. (2008). Feasibility of production methods for succinic acid derivatives: a marriage of renewable resources and chemical technology. Biofuels, Bioproducts and Biorefining, 505-529. https://doi.org/10.1002/bbb.105

Datta, R., Glassner, D. A., Jain, M. K., \& Vick Roy, J. R. (1992). US Patent No. 5,168,055. U.S.

Dessie, W., Xin, F., Zhang, W., Jiang, Y., Wu, H., Ma, J., \& Jiang, M. (2018). Opportunities, challenges, and future perspectives of succinic acid production by Actinobacillus succinogenes. Applied Microbiology and Biotechnology. https://doi.org/10.1007/s00253018-9379-5

Diaz, A. B., Blandino, A., \& Caro, I. (2018). Value added products from fermentation of sugars derived from agro-food residues. Trends in Food Science and Technology, 71(July 2017), 52-64. https://doi.org/10.1016/j.tifs.2017.10.016

Dorado, M. P., Lin, S. K. C., Koutinas, A., Du, C., Wang, R., \& Webb, C. (2009). Cereal-based biorefinery development: Utilisation of wheat milling by-products for the production of succinic acid. Journal of Biotechnology, 143(1), 51-59. https://doi.org/10.1016/j.jbiotec.2009.06.009

Du, C., Lin, S. K. C., Koutinas, A., Wang, R., Dorado, P., \& Webb, C. (2008). A wheat biorefining strategy based on solid-state fermentation for fermentative production of succinic acid. Bioresource Technology, 99(17), 8310-8315. https://doi.org/10.1016/J.BIORTECH.2008.03.019

Du, C., Lin, S. K. C., Koutinas, A., Wang, R., \& Webb, C. (2007). Succinic acid production from wheat using a biorefining strategy. Applied Microbiology and Biotechnology, 76(6), 12631270. https://doi.org/10.1007/s00253-007-1113-7

EC-DGE. (2015). From the Sugar Platform to biofuels and biochemicals. E4Tech, RE - CORD (Consorzio per la Ricerca e la Dimostrazione sulle Energie Rinnovabili), Wageningen 
1098

1099

1100

1101

1102

1103

1104

1105

1106

1107

1108

1109

1110

1111

1112

1113

1114

1115

1116

1117

1118

1119

1120

1121

1122

1123

1124

University and Research Center. https://doi.org/contract No. ENER/C2/4232012/SI2.673791

Efe, Ç., van der Wielen, L. A. M., \& Straathof, A. J. J. (2013). Techno-economic analysis of succinic acid production using adsorption from fermentation medium. Biomass and Bioenergy, 56(13), 479-492. https://doi.org/10.1016/j.biombioe.2013.06.002

Erica, H. (2004). Total Food. Cormorant, (January), 19-27. https://doi.org/10.1039/9781849730785

European Commission. (2018). World production of main daiary products. Retrieved from https://ec.europa.eu/agriculture/market-observatory/milk/latest-statistics/productionsstocks_en

FAO. (2018). FAOstat. Retrieved September 14, 2018, from http://www.fao.org/faostat/en/\#data/QC

Ferone, M., Raganati, F., Ercole, A., Olivieri, G., Salatino, P., \& Marzocchella, A. (2018). Continuous succinic acid fermentation by Actinobacillus succinogenes in a packed-bed biofilm reactor. Biotechnology for Biofuels, 11(1), 1-11. https://doi.org/10.1186/s13068018-1143-7

Ferone, M., Raganati, F., Olivieri, G., \& Marzocchella, A. (2019). Bioreactors for succinic acid production processes. Critical Reviews in Biotechnology, 39(4), 571-586. https://doi.org/10.1080/07388551.2019.1592105

Finley, K. R., Huryta, J. M., Mastel, B. M., McMullin, T. W., Poynter, G. M., Rush, B. J., ... Brady, K. M. (2013). Compositions and methods or succinate production. United States.

Fu, L., Gao, X., Yang, Y., Aiyong, F., Hao, H., \& Gao, C. (2014). Preparation of succinic acid using bipolar membrane electrodialysis. Separation and Purification Technology, 127, 212218. https://doi.org/10.1016/j.seppur.2014.02.028

Fumagalli, C. and U. by S. (2006). Succinic Acid and Succinic Anhydide. Kirk-Othmer Encyclopedia of Chemical Technology, (15). https://doi.org/10.1002/0471238961.1921030306211301.a01.pub2 
1125 Garg, N., Woodley, J. M., Gani, R., \& Kontogeorgis, G. M. (2019). Sustainable solutions by integrating process synthesis-intensification. Computers and Chemical Engineering, 126, 499-519. https://doi.org/10.1016/j.compchemeng.2019.04.030

1128 Glassner, D. A., \& Datta, R. (1992). US Patent No. 5,143,834. Chicago, US.

1129 Guettler, M. V, Rumler, D., \& Jainf, M. K. (1999). Actinobacillus succinogenes sp. nov., a novel

Gunarathne, D. S., Udugama, I. A., Jayawardena, S., Gernaey, K. V., Mansouri, S. S., \& succinic-acid-producing strain from the bovine rumen. International Journal of Systematic Bacteriology, 49(1 999), 207-216. Retrieved from http://www.ncbi.nlm.nih.gov/pubmed/10028265 Narayana, M. (2019). Resource recovery from bio-based production processes in developing Asia. Sustainable Production and Consumption, 17, 196-214. https://doi.org/10.1016/j.spc.2018.11.008

Gunnarsson, I. B., Kuglarz, M., Karakashev, D., \& Angelidaki, I. (2015). Thermochemical pretreatments for enhancing succinic acid production from industrial hemp (Cannabis sativa L.). Bioresource Technology, 182, 58-66. https://doi.org/10.1016/j.biortech.2015.01.126

Hestekin, J., Snyder, S., \& Davison, B. (2002). Direct Capture of Products from Biotransformations. Retrieved November 12, 2018, from digital.library.unt.edu/ark:/67531/metadc741289/

Holdt, S. L., \& Kraan, S. (2011). Bioactive compounds in seaweed: Functional food applications and legislation. Journal of Applied Phycology. https://doi.org/10.1007/s10811-010-9632-5

IEA Bioenergy. (2012). Bio-based Chemicals - Value Added Products from Biorefineries. https://doi.org/10.1007/978-3-319-07593-8_30

Jansen, M. L. A., \& van Gulik, W. M. (2014). Towards large scale fermentative production of succinic acid. Current Opinion in Biotechnology, 30, 190-197. https://doi.org/10.1016/j.copbio.2014.07.003

Jiang, M., Dai, W., Xi, Y., Wu, M., Kong, X., Ma, J., ... Wei, P. (2014). Succinic acid production from sucrose by Actinobacillus succinogenes NJ113. Bioresource Technology, 153, 327-332. https://doi.org/10.1016/j.biortech.2013.11.062 
1153 Jiang, M., Ma, J., Wu, M., Liu, R., Liang, L., Xin, F., ... Dong, W. (2017). Progress of succinic

1154

1155

1156

1157

1158

1159

1160

1161

1162

1163

1164

1165

1166

1167

1168

1169

1170

1171

1172

1173

1174

1175

1176

1177

1178

1179

1180 acid production from renewable resources: Metabolic and fermentative strategies. Bioresource Technology, 245(30), 1710-1717. https://doi.org/10.1016/j.biortech.2017.05.209

Joshi, R. V., Schindler, B. D., McPherson, N. R., Tiwari, K., \& Vieille, C. (2014). Development of a Markerless Knockout Method for Actinobacillus succinogenes. Applied and Environmental Microbiology, 80(10), 3053-3061. https://doi.org/10.1128/aem.00492-14

Kawasumi, R., Narita, S., Miyamoto, K., Tominaga, K. I., Takita, R., \& Uchiyama, M. (2017). One-step Conversion of Levulinic Acid to Succinic Acid Using I2/t-BuOK System: The Iodoform Reaction Revisited. Scientific Reports, 7(1), 4-11. https://doi.org/10.1038/s41598-017-17116-4

Kim, D. Y., Yim, S. C., Lee, P. C., Lee, W. G., Lee, S. Y., \& Chang, H. N. (2004). Batch and continuous fermentation of succinic acid from wood hydrolysate by Mannheimia succiniciproducens MBEL55E. Enzyme and Microbial Technology, 35(6-7), 648-653. https://doi.org/10.1016/j.enzmictec.2004.08.018

Klein, B. C., Silva, J. F. L., Junqueira, T. L., Rabelo, S. C., Arruda, P. V., Ienczak, J. L., ... Bonomi, A. (2017). Process development and techno- economic analysis of bio-based succinic acid derived from pentoses integrated to a sugarcane biorefi nery. Biofuels, Bioprod. Bioref., 11, 1051-1064. https://doi.org/10.1002/bbb.1813

Kumar, P., Barrett, D. M., Delwiche, M. J., Stroeve, P., Kumar, P., Barrett, D. M., ... Stroeve, P. (2009). Methods for Pretreatment of Lignocellulosic Biomass for Efficient Hydrolysis and Biofuel Production. Industrial \& Engineering Chemistry Research, 48, 3713-3729. https://doi.org/10.1021/ie801542g

Lee, P. C., Lee, S. Y., Hong, S. H., \& Chang, H. N. (2003). Batch and continuous cultures of Mannheimia succiniciproducens MBEL55E for the production of succinic acid from whey and corn steep liquor. Bioprocess and Biosystems Engineering, 26(1), 63-67. https://doi.org/10.1007/s00449-003-0341-1

Lee, P. C., Lee, S. Y., Hong, S. H., Chang, H. N., \& Park, S. C. (2003). Biological conversion of 
wood hydrolysate to succinic acid by Anaerobiospirillum succiniciproducens. Biotechnology Letters, 25(2), 111-114. https://doi.org/10.1023/A:1021907116361

1183 Leung, C. C. J., Cheung, A. S. Y., Zhang, A. Y. Z., Lam, K. F., \& Lin, C. S. K. (2012). 1184 Utilisation of waste bread for fermentative succinic acid production. Biochemical Engineering Journal, 65, 10-15. https://doi.org/10.1016/j.bej.2012.03.010

Li, J., Zheng, X. Y., Fang, X. J., Liu, S. W., Chen, K. Q., Jiang, M., ... Ouyang, P. K. (2011). A complete industrial system for economical succinic acid production by Actinobacillus succinogenes. Bioresource Technology, 102(10), 6147-6152. https://doi.org/10.1016/j.biortech.2011.02.093

Li, Q., Siles, J. A., \& Thompson, I. P. (2010). Succinic acid production from orange peel and wheat straw by batch fermentations of Fibrobacter succinogenes S85. Applied Microbiology and Biotechnology, 88(3), 671-678. https://doi.org/10.1007/s00253-010-2726-9

Li, Q., Wang, D., Wu, Y., Li, W., Zhang, Y., Xing, J., \& Su, Z. (2010). One step recovery of succinic acid from fermentation broths by crystallization. Separation and Purification Technology, 72(3), 294-300. https://doi.org/10.1016/j.seppur.2010.02.021

Li, Q., Yang, M., Wang, D., Li, W., Wu, Y., Zhang, Y., ... Su, Z. (2010). Efficient conversion of crop stalk wastes into succinic acid production by Actinobacillus succinogenes. Bioresource Technology, 101(9), 3292-3294. https://doi.org/10.1016/j.biortech.2009.12.064

Liang, L., Liu, R., Li, F., Wu, M., Chen, K., Ma, J., ... Ouyang, P. (2013). Repetitive succinic acid production from lignocellulose hydrolysates by enhancement of ATP supply in ... Luque, R. (2013). Food waste as a valuable resource for the production of chemicals, materials and fuels. Current situation and global perspective. Energy and Environmental Science, 6(2), 426-464. https://doi.org/10.1039/c2ee23440h (2010). Novel resin-based vacuum distillation-crystallisation method for recovery of 
1209

1210

1211

1212

1213

1214

1215

1216

1217

1218

1219

1220

1221

1222

1223

1224

1225

1226

1227

1228

1229

1230

1231

1232

1233

1234

1235

1236

succinic acid crystals from fermentation broths. Green Chemistry, 12(4), 666-671. https://doi.org/10.1039/b913021g

Lin, S. K. C., Du, C., Koutinas, A., Wang, R., \& Webb, C. (2008). Substrate and product inhibition kinetics in succinic acid production by Actinobacillus succinogenes. Biochemical Engineering Journal, 41(2), 128-135. https://doi.org/10.1016/j.bej.2008.03.013

Liu, Y.-P., Zheng, P., Sun, Z.-H., Ni, Y., Dong, J.-J., \& Zhu, L.-L. (2008). Economical succinic acid production from cane molasses by Actinobacillus succinogenes. Bioresource Technology, 99(6), 1736-1742. https://doi.org/10.1016/J.BIORTECH.2007.03.044

López-Garzón, C. S., \& Straathof, A. J. J. (2014). Recovery of carboxylic acids produced by fermentation. Biotechnology Advances, 32(5), 873-904. https://doi.org/10.1016/j.biotechadv.2014.04.002

Loureiro da Costa lira Gargalo, C. (2017). Process design, supply chain, economic and environmental analysis for chemical production in a glycerol biorefinery: Towards the sustainable design of biorefineries. Technical University of Denmark. Retrieved from http://orbit.dtu.dk/files/134655421/Carina_Gargalo_PhD_Thesis_05_2017.pdf

Lubsungneon, J., Srisuno, S., Rodtong, S., \& Boontawan, A. (2014). Nanofiltration coupled with vapor permeation-assisted esterification as an effective purification step for fermentationderived succinic acid. Journal of Membrane Science, 459, 132-142. https://doi.org/10.1016/j.memsci.2014.02.006

Luque, R., Lin, C. S. K., Du, C., MacQuarrie, D. J., Koutinas, A., Wang, R., ... Clark, J. H. (2009). Chemical transformations of succinic acid recovered from fermentation broths by a novel direct vacuum distillation-crystallisation method. Green Chemistry, 11(2), 193-200. https://doi.org/10.1039/b813409j

Macy, J. M., Ljungdahl, L. G., \& Gottschalk, G. (1978). Pathway of succinate and propionate formatin in \{IBacteroides\} \{Ifragilis\}. Journal of Bacteriology, 134(1), 84-91. Retrieved from http://jb.asm.org.ezproxy.library.wur.nl/content/134/1/84.full.pdf

Maharaj, K., Bradfield, M. F. A., \& Nicol, W. (2014). Succinic acid-producing biofilms of Actinobacillus succinogenes: Reproducibility, stability and productivity. Applied 

Microbiology and Biotechnology, 98(17), 7379-7386. https://doi.org/10.1007/s00253-014$5779-3$

Mansouri, S. S., Gargalo, C. L., Udugama, I. A., Ramin, P., Sales-Cruz, M., Sin, G., \& Gernaey, K. V. (2019). Economic Risk Analysis and Critical Comparison of Biodiesel Production Systems. In M. Tabatabaei \& M. Aghbashlo (Eds.), Biodiesel: From Production to Combustion (pp. 127-148). Cham: Springer International Publishing. https://doi.org/10.1007/978-3-030-00985-4_6

Mansouri, S. S., Ismail, M. I., Babi, D. K., Simasatitkul, L., Huusom, J. K., \& Gani, R. (2013). Systematic Sustainable Process Design and Analysis of Biodiesel Processes, 167-202. https://doi.org/10.3390/pr1020167

Maslova, O., Stepanov, N., Senko, O., \& Efremenko, E. (2019). Production of various organic acids from different renewable sources by immobilized cells in the regimes of separate hydrolysis and fermentation (SHF) and simultaneous saccharification and fermentation (SFF). Bioresource Technology, 272(August 2018), 1-9. https://doi.org/10.1016/j.biortech.2018.09.143

Mazière, A., Pepijn, P., García, A., Luque, R., \& Len, C. (2017). A review of progress in (bio)catalytic routes from/to renewable succinic acid. Biofuels, Bioproducts and Biorefining, 908-931. https://doi.org/10.1002/bbb

McKinlay, J. B., Vieille, C., \& Zeikus, J. G. (2007). Prospects for a bio-based succinate industry. Applied Microbiology and Biotechnology, 76(4), 727-740. https://doi.org/10.1007/s00253007-1057-y

Mulvihill, M. J., Beach, E. S., Zimmerman, J. B., \& Anastas, P. T. (2011). Green Chemistry and Green Engineering: A Framework for Sustainable Technology Development. Ssrn, 36, 271293. https://doi.org/10.1146/annurev-environ-032009-095500

Myriant. (2019). Myriant Technologies Bio-Based Succinic Acid Plant, US. Retrieved January 14, 2018, from https:/www.chemicals-technology.com/projects/myriant-plant/

Nghiem, N. P., Kleff, S., \& Schwegmann, S. (2017). Succinic Acid: Technology Development and Commercialization. Fermentation, 601-630. 
1266 Okino, S., Noburyu, R., Suda, M., Jojima, T., Inui, M., \& Yukawa, H. (2008). An efficient 1267 succinic acid production process in a metabolically engineered Corynebacterium 1268 glutamicum strain. Applied Microbiology and Biotechnology, 81(3), 459-464. 1269 https://doi.org/10.3923/pjn.2016.639.648

1270 Palmqvist, E., \& Hahn-Hagerdal, B. (2000). Fermentation of lignocellulosic hydrolysates. I: 1271 inhibition and detoxification. Bioresource Technology, 74, 17-24. 1272 https://doi.org/10.1016/S0960-8524(99)00160-1

1273 Pateraki, C., Patsalou, M., Vlysidis, A., Kopsahelis, N., Webb, C., Koutinas, A. A., \& Koutinas, 1274 M. (2016). Actinobacillus succinogenes: Advances on succinic acid production and 1275 prospects for development of integrated biorefineries. Biochemical Engineering Journal. 1276 https://doi.org/10.1016/j.bej.2016.04.005

1277 Pinazo, J. M., Domine, M. E., Parvulescu, V., \& Petru, F. (2015). Sustainability metrics for 1278 succinic acid production: A comparison between biomass-based and petrochemical routes. 1279 Catalysis Today, 239, 17-24. https://doi.org/10.1016/j.cattod.2014.05.035

1280 Posada, J. A., Rincón, L. E., \& Cardona, C. A. (2012). Design and analysis of biorefineries based 1281 on raw glycerol: Addressing the glycerol problem. Bioresource Technology, 111, 282-293. 1282 1283 1284 1285 1286 https://doi.org/10.1016/j.biortech.2012.01.151

Prochaska, K., Antczak, J., Regel-Rosocka, M., \& Szczygiełda, M. (2018). Removal of succinic acid from fermentation broth by multistage process (membrane separation and reactive extraction). Separation and Purification Technology, 192(October 2017), 360-368. https://doi.org/10.1016/j.seppur.2017.10.043

Raab, A. M., Gebhardt, G., Bolotina, N., Weuster-Botz, D., \& Lang, C. (2010). Metabolic engineering of Saccharomyces cerevisiae for the biotechnological production of succinic acid. Metabolic Engineering, 12(6), 518-525. https://doi.org/10.1016/j.ymben.2010.08.005

1290 Roa Engel, C. A., Straathof, A. J. J., Zijlmans, T. W., Van Gulik, W. M., \& Van Der Wielen, L. 1291 A. M. (2008). Fumaric acid production by fermentation. Applied Microbiology and 1292 Biotechnology, 78(3), 379-389. https://doi.org/10.1007/s00253-007-1341-X 
1293 Salvachúa, D., Mohagheghi, A., Smith, H., Bradfield, M. F. A., Nicol, W., Black, B. A., ...

1294 Beckham, G. T. (2016). Succinic acid production on xylose-enriched biorefinery streams by 1295 Actinobacillus succinogenes in batch fermentation. Biotechnology for Biofuels, 9(1), 1-15. 1296 https://doi.org/10.1186/s13068-016-0425-1

1297 Samuelov, N., Datta, R., Jain, M., \& Zeikus, J. (1999). Whey fermentation by 1298 Anaerobiospirillum succiniciproducens for production of a succinate-based animal feed 1299 additive. Applied and Environmental Microbiology, 65(5), 2260-2263. Retrieved from 1300 http://www.pubmedcentral.nih.gov/articlerender.fcgi?artid=91330\&tool=pmcentrez\&render 1301 type=abstract

1302 Saxena, R. K., Saran, S., Isar, J., \& Kaushik, R. (2016). Production and Applications of Succinic 1303 Acid. In Current Developments in Biotechnology and Bioengineering: Production, Isolation 1304 1305 1306 1307 1308 and Purification of Industrial Products (pp. 601-630). https://doi.org/10.1016/B978-0-44463662-1.00027-0

Shao, J., Hou, J., \& Song, H. (2010). Comparison of humic acid rejection and flux decline during filtration with negatively charged and uncharged ultrafiltration membranes. Water Research, 45(2), 473-482. https://doi.org/10.1016/j.watres.2010.09.006

Shen, N., Qin, Y., Wang, Q., Liao, S., Zhu, J., Zhu, Q., ... Huang, R. (2015). Production of succinic acid from sugarcane molasses supplemented with a mixture of corn steep liquor powder and peanut meal as nitrogen sources by Actinobacillus succinogenes. Letters in Applied Microbiology, 60(6), 544-551. https://doi.org/10.1111/lam.12399

Shi, X., Tal, G., Hankins, N. P., \& Gitis, V. (2014). Fouling and cleaning of ultrafiltration membranes: A review. Journal of Water Process Engineering, 1, 121-138. https://doi.org/10.1016/j.jwpe.2014.04.003

Shmorhum, M. A. (2015). BER-Myriant Succinic Acid Biorefinery. Lake Providence, Louisiana. Succinity. (2019). Biobased Succinic Acid. Retrieved August 25, 2019, from 1319 Sun, Y., Yan, L., Fu, H., \& Xiu, Z. (2014). Salting-out extraction and crystallization of succinic 1320 acid from fermentation broths. Process Biochemistry, 49(3), 506-511. 
1322 Szczygiełda, M., Antczak, J., \& Prochaska, K. (2017). Separation and concentration of succinic 1323 acid from post-fermentation broth by bipolar membrane electrodialysis (EDBM). Separation and Purification Technology, 181, 53-59. https://doi.org/10.1016/j.seppur.2017.03.018

1326

1327 1328 1329

Thuy, N. T. H., Kongkaew, A., Flood, A., \& Boontawan, A. (2017). Fermentation and crystallization of succinic acid from Actinobacillus succinogenes ATCC55618 using fresh cassava root as the main substrate. Bioresource Technology, 233. https://doi.org/10.1016/j.biortech.2017.02.114

Van Der Werf, M. J., Guettler, M. V., Jain, M. K., \& Zeikus, J. G. (1997). Environmental and physiological factors affecting the succinate product ratio during carbohydrate fermentation by Actinobacillus sp. 130Z. Archives of Microbiology, 167(6), 332-342. https://doi.org/10.1007/s002030050452

van Heerden, C. D., \& Nicol, W. (2013). Continuous succinic acid fermentation by Actinobacillus succinogenes. Biochemical Engineering Journal, 73, 5-11. https://doi.org/10.1016/j.bej.2013.01.015

Vassilev, S. V., \& Vassileva, C. G. (2016). Composition, properties and challenges of algae biomass for biofuel application: An overview. Fuel, 181, 1-33. https://doi.org/10.1016/j.fuel.2016.04.106

Vemuri, G., Eiteman, M., \& Altman, E. (2002). Succinate production in dual-phase Escherichia coli fermentations depends on the time of transition from aerobic to anaerobic conditions. Applied and Environmental Microbiology, 28, 325-332. https://doi.org/10.1038/sj/jim/7000250

Wan, C., Li, Y., Shahbazi, A., \& Xiu, S. (2008). Succinic acid production from cheese whey using Actinobacillus succinogenes 130 Z. Applied Biochemistry and Biotechnology, 145(13), 111-119. https://doi.org/10.1007/s12010-007-8031-0

Wang, C., Li, Q., Tang, H., Yan, D., Zhou, W., Xing, J., \& Wan, Y. (2012). Membrane fouling mechanism in ultrafiltration of succinic acid fermentation broth. Bioresource Technology, 
Wang, C., Li, Q., Tang, H., Zhou, W., Yan, D., Xing, J., \& Wan, Y. (2013). Clarification of succinic acid fermentation broth by ultrafiltration in succinic acid bio-refinery. Journal of Chemical Technology and Biotechnology, 88(3), 444-448. https://doi.org/10.1002/jctb.3834

Wang, D., Li, Q., Yang, M., Zhang, Y., Su, Z., \& Xing, J. (2011). Efficient production of succinic acid from corn stalk hydrolysates by a recombinant Escherichia coli with ptsG mutation. Process Biochemistry. https://doi.org/10.1016/j.procbio.2010.09.012

Weastra. (2012). Determination of market potential for selected platform chemicals. BioConSepT, (January), 1-173. Retrieved from http://www.bioconsept.eu/wpcontent/uploads/BioConSepT_Market-potential-for-selected-platform-chemicals_ppt1.pdf

Werpy, T., \& Petersen, G. (2004). Top value added chemicals from biomass. Volume I: Results of screening for potential candidates from sugars and synthesis gas. Produced by the staff at the Pacific Northwest National Laboratory (PNNL) and the National Renewable Energy Laboratory (NREL). https://doi.org/10.2172/15008859

Xu, C., Zhang, J., Zhang, Y., Guo, Y., Xu, H., \& Xu, J. (2018). Long chain alcohol and succinic

Yedur, S., Berglund, K. A., \& Dunuwila, D. D. (2001). Succinic acid production and acid co-production process based on full utilization of lignocellulosic materials. Current Opinion in Green and Sustainable Chemistry, 14, 1-9. https://doi.org/10.1016/j.cogsc.2018.04.012 purification. U.S. https://doi.org/10.1038/incomms1464

Yu, J. H., Zhu, L. W., Xia, S. T., Li, H. M., Tang, Y. L., Liang, X. H., ... Tang, Y. J. (2016). Combinatorial optimization of CO2transport and fixation to improve succinate production by promoter engineering. Biotechnology and Bioengineering, 113(7), 1531-1541. https://doi.org/10.1002/bit.25927

Zeikus, J. G., Jain, M. K., \& Elankovan, P. (1999). Biotechnology of succinic acid production and markets for derived industrial products. Applied Microbiology and Biotechnology, 51(5), 545-552. https://doi.org/10.1007/s002530051431

Zhang, A. Y. Z., Sun, Z., Leung, C. C. J., Han, W., Lau, K. Y., Li, M., \& Lin, C. S. K. (2013). 
Valorisation of bakery waste for succinic acid production. Green Chemistry, 15(3), 690695. https://doi.org/10.1039/c2gc36518a

1379 Zhang, T., Kumar, R., Tsai, Y. Du, Elander, R. T., \& Wyman, C. E. (2015). Xylose yields and 1380 relationship to combined severity for dilute acid post-hydrolysis of xylooligomers from hydrothermal pretreatment of corn stover. Green Chemistry, 17(1), 394-403. https://doi.org/10.1039/c4gc01283f

1383 Zhang, W., Luo, J., Ding, L., \& Ja, M. Y. (2015). A Review on Flux Decline Control Strategies 1384 in Pressure-Driven Membrane Processes. https://doi.org/10.1021/ie504848m

1385 Zheng, P., Dong, J.-J., Sun, Z.-H., Ni, Y., \& Fang, L. (2009). Fermentative production of 1386 succinic acid from straw hydrolysate by Actinobacillus succinogenes. Bioresource 1387 Technology, 100(8), 2425-2429. https://doi.org/10.1016/J.BIORTECH.2008.11.043

1388 Zheng, P., Fang, L., Xu, Y., Dong, J. J., Ni, Y., \& Sun, Z. H. (2010). Succinic acid production 1389 from corn stover by simultaneous saccharification and fermentation using Actinobacillus 1390 succinogenes. Bioresource Technology, 101(20), 7889-7894.

1391 https://doi.org/10.1016/j.biortech.2010.05.016

1392 
1394 Table S1. Summary of advantages and disadvantages of three of the most relevant microorganisms for SA production.

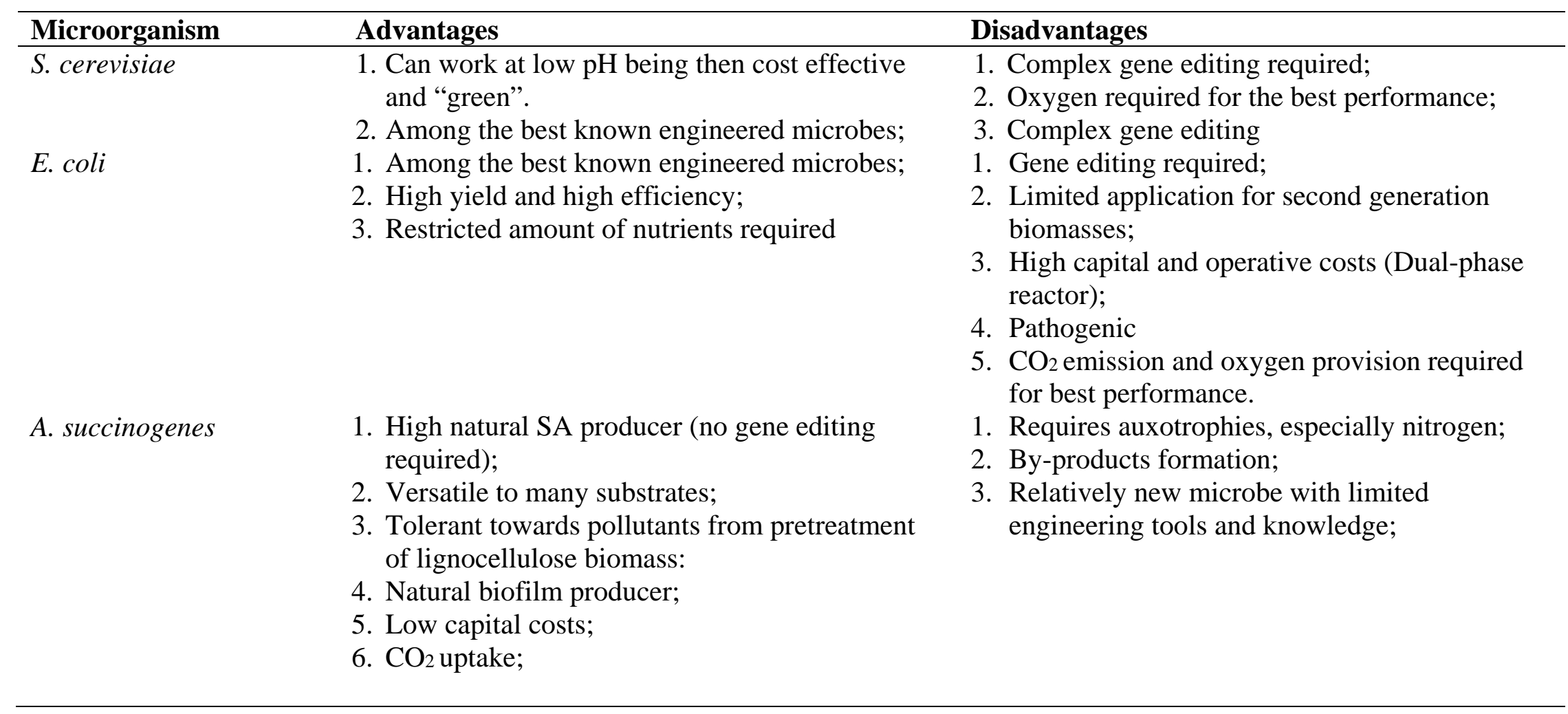


BioAmber

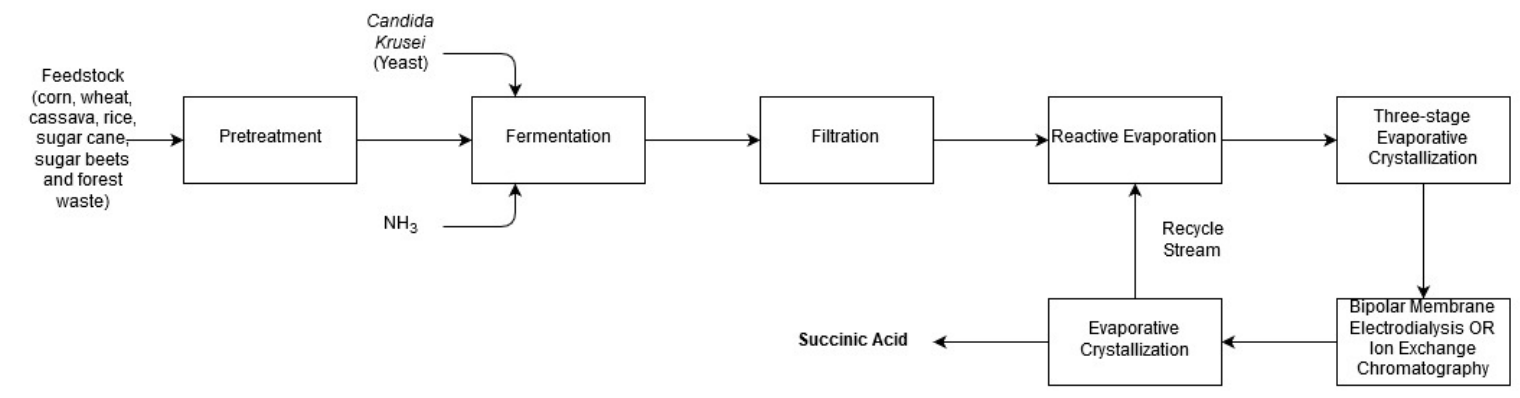

\section{Reverdia}


Myriant

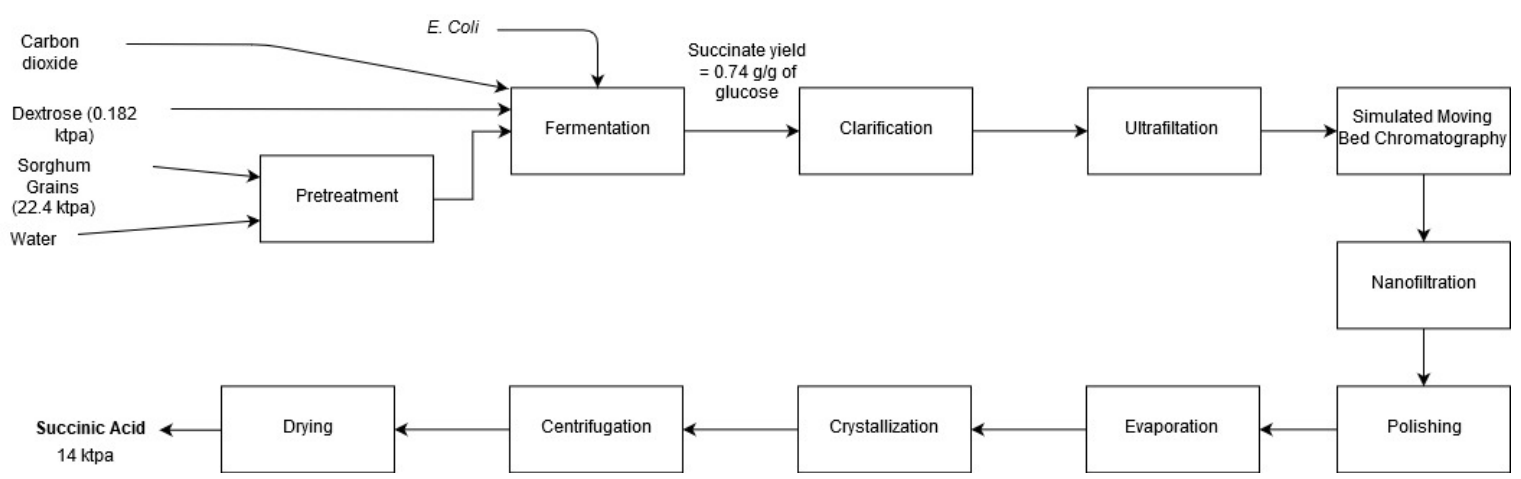

1397 Figure S1. Presumed processes used by the companies producing SA from fermentation at

1398 commercial scale. While the Myriant flow process was released by the company itself

1399 (Shmorhum, 2015), the other processes were draw based on the review of Nghiem et al., (2017). 